\title{
Modelling credit spreads with time volatility, skewness, and kurtosis
}

\author{
Ephraim Clark ${ }^{1}$. Selima Baccar ${ }^{2}$
}

Published online: 4 September 2015

(C) The Author(s) 2015. This article is published with open access at Springerlink.com

\begin{abstract}
This paper seeks to identify the macroeconomic and financial factors that drive credit spreads on bond indices in the US credit market. To overcome the idiosyncratic nature of credit spread data reflected in time varying volatility, skewness and thick tails, it proposes asymmetric GARCH models with alternative probability density functions. The results show that credit spread changes are mainly explained by the interest rate and interest rate volatility, the slope of the yield curve, stock market returns and volatility, the state of liquidity in the corporate bond market and, a heretofore overlooked variable, the foreign exchange rate. They also confirm that the asymmetric GARCH models and Student- $t$ distributions are systematically superior to the conventional GARCH model and the normal distribution in in-sample and out-of-sample testing.
\end{abstract}

Keywords Credit spreads · Asymmetric GARCH · Skewness · Kurtosis · Student- $t$ distribution

JEL Classification C58 $\cdot$ F34 · G15 - G17

\section{Introduction}

The aim of our study is to identify the macroeconomic and financial factors and model the forces that drive credit spreads on bond indices in the US credit market. Much of the research on corporate credit risk focuses on the credit spreads, which is a common measure of a company's borrowing cost and creditworthiness. The theoretical work on credit spreads,

Selima Baccar

selima.baccar@yahoo.fr

Ephraim Clark

e.clark@mdx.ac.uk

1 Middlesex University, The Burroughs, London NW4, UK

2 IHEC Carthage, 2016 Carthage Présidence, Tunis, Tunisia 
defined as the difference between the interest rate the corporate borrower pays on its debt and the rate paid by the Treasury on debt of a comparable maturity, suggests that they change over time for reasons such as varying market conditions, changes in issuer credit ratings, or changes in expectations regarding the recovery rate (see Campbell and Huisman 2003; Longstaff and Schwartz 1995, among others). The empirical literature (e.g. Delianedis and Geske 2001; Collin-Dufresne et al. 2001; Elton et al. 2001; Cremers et al. 2008; Gilchrist and Zakrajsek 2011; Huang and Huang 2012) suggests that besides the theoretical factors related to default risk, there is also a set of macro-economic factors that explain a proportion of the variation in credit spreads. This literature generally uses standard econometric techniques that do not address the particularities of the credit spread data, such as time varying volatility, skewness and thick tails, which could bias the results. However, empirical evidence shows that credit spreads are likely to have time varying, non-normal distributions. For example, Pedrosa and Roll (1998), Cai and Jiang (2008) and Hibbert et al. (2011) showed that US corporate credit spread indexes reveal a high level of persistence in volatility and in a study of the Euro zone fixed income markets Alizadeh and Gabrielsen (2013) showed that credit spread changes are likely to be skewed, fat-tailed, and change behaviour over time. ${ }^{1}$ Ignoring characteristics such as these can bias the results and compromise the estimation of credit spread models. This paper addresses this shortcoming by proposing asymmetric GARCH models with alternative probability density functions to identify the variables that drive changes in credit spreads.

The contribution of this paper takes several directions. In the major contribution, we identify a set of variables that are significant determinants of changes in credit spreads. These variables include those suggested by the structural models, such as interest rates, interest rate volatility, the slope of the yield curve, stock market returns and stock market return volatility, as well as variables associated with market conditions reflected in bond market liquidity and exchange rate risk. Exchange rate risk is a mostly overlooked variable in the credit risk literature whose importance has only recently attracted analytical interest (e.g. Jankowitsch and Pichler 2005; Galai and Wiener 2012) due to the development of financial markets and the internationalization of business activities and the unpredictable movements of exchange rates. Overall, all the variables investigated in this paper have the expected signs and the ability to explain changes in credit spreads over all ratings and maturities under consideration.

We also show that one can improve overall estimations by using the asymmetric GARCH model with fat-tailed densities. Compared to the traditional GARCH model, the AGARCH and GJR-GARCH models provide a better description and more parsimonious representation of credit spread data. They also allow for the increased flexibility provided by the Student- $t$ specification. This result holds for all rating categories and maturities and is robust to insample and out-of-sample testing with significant implications for risk management and the pricing of credit derivatives.

The rest of this paper is organized as follows. Section 2 gives an overview of the literature on credit spreads. Section 3 describes the data and presents the time series properties of credit spreads. Section 4 illustrates the methodology of the GARCH models used in the paper. Section 5 presents our empirical results and analysis, Sect. 6 presents the out-ofsample robustness tests. Finally, Sect. 7 summarizes and concludes the main findings of the paper.

\footnotetext{
1 The Alizadeh and Gabrielsen (2013) results could be biased by their failure to include any control variables. For example, in a study comparing the dynamics of credit spreads in the US and Euro zone markets, Van Landschoot (2008) shows that credit spreads in the US market are more sensitive to fluctuations in the interest rate and the credit cycle than those in the Euro zone market.
} 


\section{Determinants of credit spreads}

\subsection{Theoretical and empirical background}

The theoretical literature on default risk generally follows the structural models that spring from the option pricing work of Black and Scholes (1973) and Merton (1974). These contingent claim models assume that the value of the firm follows a continuous time stochastic process where default occurs when the value of the firm falls below a predetermined boundary. ${ }^{2}$ They provide an intuitive theoretical framework to assess the main determinants of yield spreads and, in theory, these determinants should be good predictors of credit spread changes. In practice, however, they seem to have limited explanatory power (e.g. Jones et al. 1984; Ogden 1987; Delianedis and Geske 2001; Elton et al. 2001; Lyden and Saraniti 2000; Houweling et al. 2005; Ericsson and Renault 2006), leading to the belief that other common factors exist that explain the remaining variation.

The structural models present the risk-free interest rate as a relevant factor in assessing risky debt. These models produce an inverse relationship between credit spreads and interest rates. The rationale behind this negative relationship is that an increase in the interest rate implies an increase in the expected growth rate of the firm's asset value, which in turn reduces the probability of default and the yield spread. Furthermore, higher interest rates and a positively sloped yield curve are usually associated with improving economic activity and thus lower yield spreads.

Extending the Black-Scholes/Merton model, Longstaff and Schwartz (1995) showed that an increase in the risk-free interest rate leads to an increase in the drift of the process that governs the evolution of the value of the firm and that yield spreads fall when the level and the slope of the default-free term structure rise. Using a sample of credit spreads for corporate bonds on the US market, Collin-Dufresne et al. (2001) supported this result and note that the credit spreads and the level of interest rates are negatively correlated. They predict a strong interest rate effect for bonds with high leverage or a lower credit quality. Other studies based on the structural models, such as Ericsson and Renault (2006) and Avramov et al. (2007) also find a negative relation between interest rates and spreads.

One of the major criticisms of the original Black-Scholes/Merton model is the constancy of the interest rate and the absence of interest rate risk. Longstaff and Schwartz (1995) introduced stochastic interest rates in the valuation of risky debt. Several empirical studies, such as Kao (2000), Collin-Dufresne et al. (2001) and Ohyama and Sugimoto (2007), showed that the volatility of interest rates has an important and significant impact on changes in credit spreads. Longstaff and Schwartz (1995) also pointed out the importance of the slope of the term structure, measured as the difference between the long rate and the short rate as a predictor of future short-term rates expected by the market. In the long term, short-term rates should converge to the long-term interest rates. Thus, an increasing term structure indicates that the market expects an increase in short rates in the future. At the macroeconomic level, the slope of the yield curve is often used as an indicator of economic growth (Fama and French 1989; Estrella and Hardouvelis 1991; Estrella and Mishkin 1998; Bernard and Gerlach 1998). Indeed, an increase in the slope indicates economic growth while a decrease in the slope of the term structure, even turning negative, reflects an economic recession. Economic growth and recession can affect the firm's growth's rate and cause an increase/decrease in the probability of default and credit spreads. These arguments are consistent with the results of

2 Reduced form models are based on the studies of Jarrow and Turnbull (1995) and Duffie and Singleton (1999) who treat default as a pure jump process. 
Duffee (1998), Collin-Dufresne et al. (2001) and Van Landschoot (2008), who highlighted the negative correlation between the slope of the risk free term structure and changes in credit spreads on the bond market.

In the structural models, the leverage of the company is another key element in determining the price of risky debt issued by the firm. The rationale is that firms with low asset values relative to their debt value are more likely to default. In these models, default is triggered when the ratio of leverage approaches unity. Thus, the decline in stock prices or the probability of a decline in stock prices through an increase in volatility causes an increase in leverage and the firm's default risk, which in turn leads to an increase in the spreads and a decline in the debt's price. The negative relationship between stock returns and credit spreads has been validated by many empirical studies: Ramaswami (1991), Shan (1994) and Kwan (1996) at the level of the individual firm; Keim and Stambaugh (1986), Campbell and Ammer (1993) at the aggregate level; and Blume et al. (1991) and Cornell and Gren (1991) at the portfolio level. Campbell and Taksler (2003) found a significant positive relationship between asset volatility and credit spreads.

Under the assumption of perfect and complete markets where trading takes place continuously, the theoretical structural models intentionally ignore the role of liquidity risk in the estimation of credit spreads. However, as discussed above, many tests of the structural models show that they systematically underestimate observed credit spreads. One of the reasons for this is that they do not consider the liquidity factor. For example, Chordia et al. (2003), Chacko (2005), Driessen (2005) and Downing et al. (2007) showed that liquidity risk is a major determinant of observed credit spreads. ${ }^{3}$ Other studies including Collin-Dufresne et al. (2001), Delianedis and Geske (2001), Perraudin and Taylor (2003), Houweling et al. (2005), Ericsson and Renault (2006) and Van Landschoot (2008), De Jong and Driessen (2012), Chen et al. (2014), Tseng et al. (2014) and Schwartz (2014), also showed a strong, negative relationship between credit spreads and liquidity. ${ }^{4}$ In fact, a decrease in the corporate bond market's liquidity implies a market preference for less risky assets and a higher risk premium to cover the liquidity risk.

The development of financial markets and the internationalization of business activities have highlighted the increased importance of exchange rate risk in the determination of credit spreads. This risk is caused by the unpredictable movements of exchange rates and the effect of exchange rates on company performance. For example, many studies, such as Jorion (1990), Agarwal and Ramaswami (1992), Bodnar and Gentry (1993), Amihud (1994), Choi and Prasad (1995), Donnelly and Sheehy (1996), He and Ng (1998), Miller and Reuer (1998), Hagelin and Prambourg (2004) and Clark and Mefteh (2011) to mention only a few, documented the effect of exchange rate fluctuations on firm performance and the firm's risk profile. ${ }^{5}$ Pesaran et al. (2006) showed that severe fluctuations in exchange rates may significantly affect the companies' balance sheets, particularly international ones, and increase their default risk. Jankowitsch and Pichler (2005) documented a strong, positive relationship between credit risk and exchange rates. Galai and Wiener (2012) found that the probability of insolvency and the costs of financing for companies with multi-currency liabilities depend on the correlation between the company's rate of return and the exchange rate with respect to the borrowed currency.

\footnotetext{
3 De Jong and Driessen (2012) showed that credit spreads are strongly affected by fluctuations of liquidity on the Treasury bond market and on the stock market.

4 The reduced form models of Duffie and Singleton (1999) and Driessen (2005) also showed the importance of the role of liquidity in the determination of spreads.

5 See Muller and Verschoor (2006) for a comprehensive review of the literature.
} 
The overall conclusion of the foregoing discussion is that the structural models are important determinants of observed credit spreads in the markets. They capture a large proportion of the spreads associated with default risk. Observed spreads, however, are driven by micro and macro market forces other than default risk. Thus, a complete model of credit spreads should include the variables associated with default risk, the organization of the bond market itself reflected in supply and demand, as well as the macro variables that can affect both default risk and market supply and demand.

\subsection{Variable selection}

The preceding section highlights the main variables suggested by theory and practice that are likely to determine credit spreads in the fixed income markets. The variables suggested by the structural models of financial theory include the risk-free interest rate, the volatility of the risk free interest rate, the slope of the yield curve, stock market returns and the volatility of stock market returns. Practical considerations of macro and micro market structure suggest that along with these variables liquidity and exchange rate fluctuations are also relevant factors in assessing risky debt.

We use the 10-year US government bond yield as a measure of the risk-free interest rate. As discussed above there should be an inverse relationship between credit spreads and interest rates. The rationale behind this negative relationship is that an increase in the interest rate implies an increase in the expected growth rate of the firm's asset value, which in turn reduces the probability of default and the yield spread. Furthermore, higher interest rates and a positively sloped yield curve are usually associated with improving economic activity and thus lower yield spreads.

To measure the volatility of interest rates, we use the historical volatility of the risk free rate derived from the time series of past market prices. It corresponds to the annualized standard deviation of daily returns. The expected sign on the volatility coefficient is ambiguous. In the theoretical model of Longstaff and Schwartz discussed above as well as the empirical study of Collin-Dufresne et al. (2001) the sign can be either positive or negative depending on the maturity of the individual bond. Low credit ratings and long term maturities are associated with more uncertainty and higher spreads, while high ratings and low maturity are associated with less uncertainty and lower spreads.

We define the slope of the yield curve as the difference between the 10-year US government interest rate and the 3-month treasury rate. From the evidence provided in the foregoing discussion, the yield curve acts as a predictor of future short term rates and economic activity. An increasing (decreasing) term structure indicates that the market expects an increase (decrease) in short rates in the future. An increase (decrease) in the slope of the term structure, indicates economic growth (recession), which in turn can increase (reduce) the firm's growth rate and cause a decrease (increase) in the probability of default and credit spreads. Thus, we expect a negative relationship between the slope of the yield curve and credit spreads.

In structural modeling, the leverage of the individual company is a key element in determining the price of risky debt issued by the firm. The higher (lower) the value of the firm, the lower (higher) is the likelihood that firm value will fall far enough to trigger default. Since our study deals with bond indices rather than individual corporate bonds, it cannot use the firm's leverage as a variable in the model. But, the discussion above showed that the overall stock market is a good proxy at the level of bond indices. To proxy the US stock market performance we use the daily returns of S\&P500 index and we expect a negative relationship between stock market returns and bond spreads. 
Another feature of the structural models highlighted above is the important role of firm asset volatility. The volatility reflects the uncertainty faced by the company. In this context, greater asset volatility implies a higher (lower) likelihood of significant changes in the level of leverage. Thus, an increase (decrease) in asset volatility increases (decreases) the likelihood that the leverage ratio approaches the level where the value of the company's assets falls below the default threshold. As in the preceding paragraph, since we are using bond indices, we use the stock market indices in place of the individual firm asset values to estimate volatility. In this paper, we use the implied volatility of the S\&P500 stock index as a proxy for the volatility in the US stock market. We expect a positive relationship between the stock market's volatility and the credit spreads.

The empirical literature presented in the preceding section has shown the significant, negative effect of bond market liquidity on the evolution of credit risk. Following Castagnetti and Rossi (2013), we proxy the liquidity on the US corporate bond market by the long-term US Dollar swap spreads. We consider the difference between the fixed-rate of a 5-year LIBOR swap and the 5-year market interest rate on government bonds. We expect to find a negative relationship.

Finally, to account for the internationalization of financial markets and business activities and how it can effect on the competitiveness, riskiness and profitability of commercial or industrial firms, we introduce the US Dollar real effective exchange rate. Since higher exchange rate volatility increases uncertainty for the firm with respect to profits and leverage, we expect a negative relationship between changes in the exchange rate and credit spreads.

The model we test has the form:

$$
\begin{aligned}
\Delta C S_{t}= & C+\beta_{1} \Delta r_{t}+\beta_{2} \Delta \sigma_{t}^{r}+\beta_{3} \Delta \text { Slop }_{t}+\beta_{4} \Delta R_{t}^{\text {stoxx }}+\beta_{5} \Delta \sigma_{t}^{\text {stoxx }} \\
& +\beta_{6} \Delta \operatorname{Liq}_{t}+\beta_{7} \Delta \text { Exch }_{t}+\varepsilon_{t}
\end{aligned}
$$

where $C$ is a constant, $\Delta r_{t}$ is the change in the risk free rate, $\Delta \sigma_{t}^{r}$ is the change in the volatility of the risk free rate, $\Delta S$ Slop $t$ is the change in the yield curve, $\Delta R_{t}^{\text {stoxx }}$ is the change in returns on the S\&P 500, $\Delta \sigma_{t}^{\text {stoxx }}$ is the change in volatility of returns on the S\&P 500, $\Delta L i q_{t}$ is the change in bond market liquidity, $\Delta E x c h_{t}$ is the change in the exchange rate, the $\beta_{i}$ 's are the estimated coefficients and $\varepsilon_{t}$ is the error term.

Table 1 summarizes the explanatory variables used in the model, as well as the expected signs.

\section{Data}

\subsection{Data characteristics}

In this study, we focus on the American debt market. The US debt market has a much longer history and is broader and deeper in terms of market share and number of bonds than its European counterpart. In fact, the US market is the largest, most organized and most liquid market of private debt market in the world. Furthermore, it plays a much larger role in corporate financing than the European market where corporates have tended to rely more on bank loans.

We use daily data on the Options Adjusted Spreads (OAS) indices published by Bank of America Merrill Lynch, from 25 January 2011 to 25 January 2013. The sample period was chosen to include the regulatory and behavioral changes inspired by the financial crisis while avoiding the biases introduced by the exceptional volatility observed in the financial markets during the crisis and the uncertainty surrounding the regulatory response to this volatility. 
Table 1 Overview of determinants of yield spreads changes

\begin{tabular}{|c|c|c|c|}
\hline Variables & Designation & Description & Expected sign \\
\hline \multicolumn{4}{|c|}{ 1. Default risk factors } \\
\hline \multicolumn{4}{|c|}{ Interest rate variables } \\
\hline$\Delta r_{t}$ & Risk free interest rate & Changes in 10-year US government bond yield & - \\
\hline$\Delta \sigma_{t}^{r}$ & Interest rate volatility & $\begin{array}{l}\text { Changes in historic volatility of daily 10-year } \\
\text { US government bond yield }\end{array}$ & $?$ \\
\hline$\Delta S l o p_{t}$ & Slope of yield curve & $\begin{array}{l}\text { Changes in (10-year US government bond } \\
\text { yield - } 3 \text { month US treasury bill rate) }\end{array}$ & - \\
\hline \multicolumn{4}{|c|}{ Stock market variables } \\
\hline$\Delta R_{t}^{s t o x x}$ & Stock market return & Changes in log returns of S\&P500 index & - \\
\hline$\Delta \sigma_{t}^{\text {stoxx }}$ & Stock market volatility & Changes in implied volatility of S\&P500 & + \\
\hline \multicolumn{4}{|c|}{ 2. Liquidityrisk factor } \\
\hline$\Delta L i q_{t}$ & Bond market liquidity & $\begin{array}{l}\text { Changes in 5-year US Dollar interest swap } \\
\text { spreads }\end{array}$ & - \\
\hline \multicolumn{4}{|c|}{ 3. Exchange risk factor } \\
\hline$\Delta E x c h_{t}$ & Real effective exchange rate & $\begin{array}{l}\text { Changes in US Dollar real effective exchange } \\
\text { rate }\end{array}$ & + \\
\hline
\end{tabular}

Following the methodology in the empirical studies cited above, we obtain the credit spreads by taking the difference between the risky index yield and a government bond yield of the same maturity range. OAS spreads are calculated from the index's returns combining all the bonds of a particular rating category and the term structure of Treasury bill rates. The OAS spreads take into account the specific bond's optional clauses. They are constructed from the adjusted spreads for each bond in the index, and weighted by market capitalization. The OAS method integrates a binomial process of short-term interest rate evolution.

The use of bond index data is motivated by the fact that transaction data for individual bonds is not easily accessible. Otherwise, the sample of bond indexes ensures completeness since it incorporates information from the entire universe of investment grade fixed income securities in the US market. Bond indexes are constructed daily using prices obtained from market participants, thus they reflect new information in a timely manner for a more accurate calculation of the credit spread at a given point in time.

Merrill Lynch Corporate Bond Indices are partitioned by S\&P credit ratings and by maturity. In this study, we investigate nine different corporate credit spread categories over the relevant time period: four rating categories (AAA, AA, A and $\mathrm{BBB}$ ) and five maturity ranges (1-3, 3-5, 5-7, 7-10 and over 10 years).

Summary statistics are presented in Table 2. As expected, spreads increase as the credit rating falls or the maturity lengthens. However, the examination of mean and median first differences in spreads shows that there is no general trend in terms of spread movement across credit rating or maturity. The volatility of credit spreads, as measured by standard deviation, tends to be higher for spreads on lower rated bonds and bonds with longer maturities. Beyond 5-7 years' maturity, credit spread volatility begins to decrease.

\subsection{Time series properties}

Figures 1 and 2 illustrate the time series of levels and changes in credit spreads respectively (by rating and maturity). The plot of the credit spread series reveals the presence of 
Table 2 Summary statistics

\begin{tabular}{lllllll}
\hline \multicolumn{2}{l}{ Levels } & & & & \multicolumn{2}{l}{ Differences } \\
\cline { 2 - 3 } \cline { 5 - 6 } Mean & Med. & SD & & Mean & Med. & SD \\
\hline
\end{tabular}

Panel A: By rating

\begin{tabular}{lrrrrrr} 
AAA & 72.259 & 67 & 14.315 & -0.005 & 0 & 1.594 \\
AA & 127.731 & 121 & 32.888 & -0.048 & 0 & 2.239 \\
A & 169.554 & 159 & 39.799 & -0.059 & 0 & 2.289 \\
BBB & 240.894 & 243 & 40.955 & -0.023 & 0 & 2.332 \\
Global & 191.608 & 189 & 37.388 & -0.030 & 0 & 2.176 \\
Panel B: By maturity & & & & & \\
1-3 years & 133.431 & 126 & 34.258 & -0.061 & 0 & 2.123 \\
3-5 years & 183.846 & 177 & 44.762 & -0.055 & 0 & 2.213 \\
5-7years & 213.222 & 202 & 48.153 & -0.082 & 0 & 2.586 \\
7-10years & 211.762 & 213 & 37.794 & -0.009 & 0 & 2.419 \\
+10 years & 211.606 & 217 & 31.646 & 0.025 & 0 & 2.138 \\
\hline
\end{tabular}

Source: Merrill Lynch, Authors' Calculations

Table 3 Statistical tests

\begin{tabular}{|c|c|c|c|c|c|c|}
\hline & \multicolumn{2}{|l|}{ Jarque-Bera test } & \multicolumn{2}{|c|}{ Ljung-Box Q } & \multicolumn{2}{|c|}{ Engle's LM test } \\
\hline & $\chi^{2}$ & $p$ value & $\chi^{2}$ & $p$ value & $\chi^{2}$ & $p$ value \\
\hline \multicolumn{7}{|c|}{ Panel A: By rating } \\
\hline AAA & $212,075.277 *$ & 0.0000 & 37.826 & 0.5685 & 0.021 & 0.8855 \\
\hline AA & $2975.152 *$ & 0.0000 & $134.742 *$ & 0.0000 & 0.891 & 0.3452 \\
\hline A & $963.233^{*}$ & 0.0000 & $281.605^{*}$ & 0.0000 & $14.443^{*}$ & 0.0001 \\
\hline $\mathrm{BBB}$ & $1149.588^{*}$ & 0.0000 & $298.011 *$ & 0.0000 & $9.638^{*}$ & 0.0019 \\
\hline Global & $1481.587 *$ & 0.0000 & $285.758^{*}$ & 0.0000 & $6.974 *$ & 0.0083 \\
\hline \multicolumn{7}{|c|}{ Panel B: By maturity } \\
\hline $1-3$ years & $1029.979^{*}$ & 0.0000 & $200.876^{*}$ & 0.0000 & $12.466^{*}$ & 0.0001 \\
\hline $3-5$ years & $579.868^{*}$ & 0.0000 & $371.885^{*}$ & 0.0000 & $10.536^{*}$ & 0.0000 \\
\hline $5-7$ years & $963.540 *$ & 0.0000 & $320.897 *$ & 0.0000 & $14.098 *$ & 0.0000 \\
\hline 7-10 years & $928.884 *$ & 0.0000 & $226.552 *$ & 0.0000 & $14.287^{*}$ & 0.0002 \\
\hline+10 years & $1757.656^{*}$ & 0.0000 & $247.099 *$ & 0.0000 & $13.341^{*}$ & 0.0000 \\
\hline
\end{tabular}

* Significance at $5 \%$ level

heteroscedasticity. Periods of high volatility and others of lower volatility that occur in clusters are observed. Table 3 shows the results of some statistical tests performed on the first difference series of credit spreads.

The Jarque-Bera test rejects the null hypothesis of zero skewness and zero excess kurtosis. This confirms the non-normality of our empirical series. The Ljung-Box-Pierce test allows us to deduce the lack of randomness in the data and the presence of autocorrelation. Finally, the Engle's ARCH test also rejects the null hypothesis that the credit spreads form a random sequence of normal disturbances, hence the presence of heteroscedasticity. These features suggest the use of a GARCH model to capture the time varying volatility of credit spreads. 

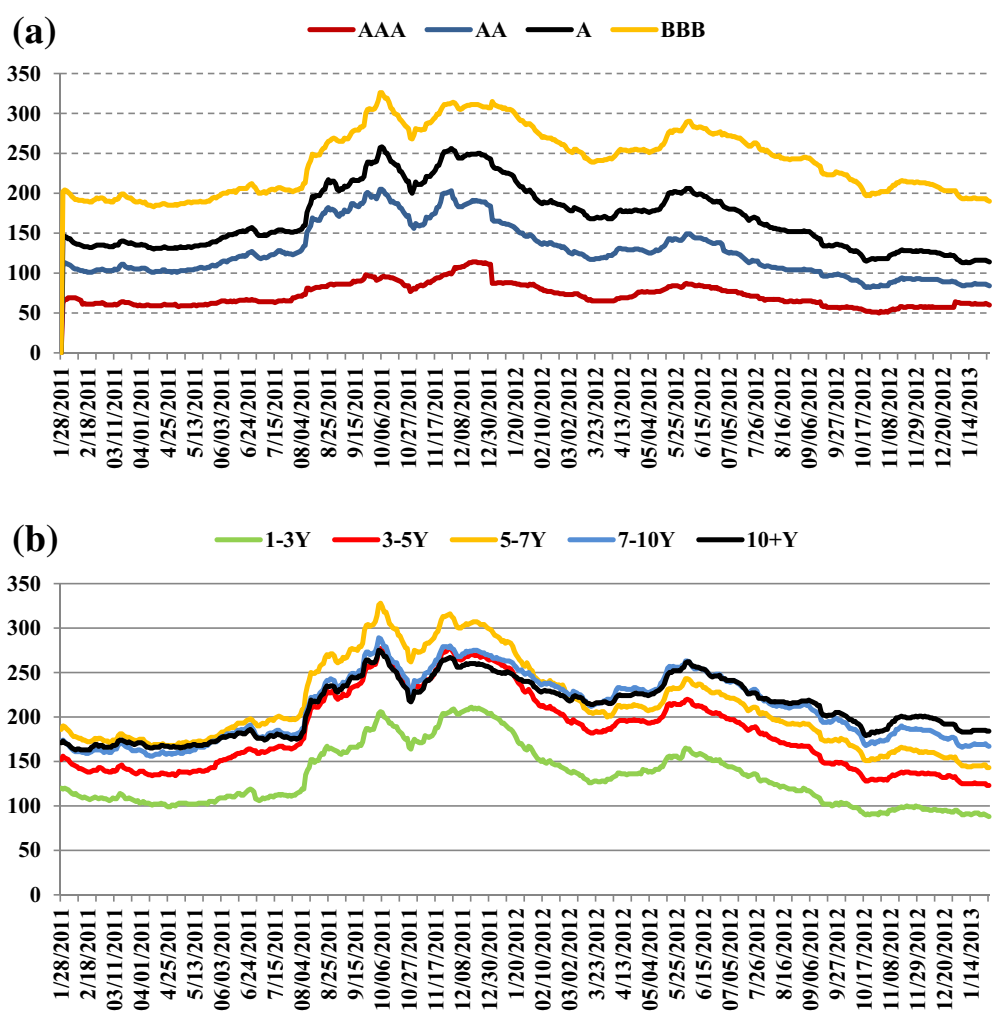

Fig. 1 a US Dollar corporate credit spreads by rating. b US Dollar corporate credit spreads by maturity

\section{Methodological framework}

In this paper, we estimate a number of conditional heteroskedastic time-series models, in order to capture the ARCH effects and to represent the observed autocorrelation structure in daily credit spread changes. The original work of Engle (1982) and Bollerslev (1986) introduced that generalized autoregressive conditional heteroskedastic $(\mathrm{GARCH})$ models were useful when modeling the time-varying volatility of the financial assets.

The standard GARCH $(p, q)$ model allows the conditional variance to be dependent upon previous own lags. It expresses the variance $\left(h_{t}\right)$ at time $t$ as:

$$
h_{t}=\omega+\sum_{i=1}^{p} \alpha_{i} \varepsilon_{t-i}^{2}+\sum_{j=1}^{q} \beta_{j} h_{t-j}
$$

where $h_{t}$ denotes the conditional variance, $\alpha$ the ARCH effect, and $\beta$ the GARCH effect.

The GARCH model is easy to estimate and allows performing diagnostic tests. However it presents some limitations. The GARCH model only captures some of the skewness and the kurtosis in the financial data. Moreover, the non-negativity conditions of variance may be violated by the estimated method since the coefficients of model can be negative. The GARCH model also does not allow for any direct feedback between the conditional variance and the conditional mean and cannot account for leverage effects. 

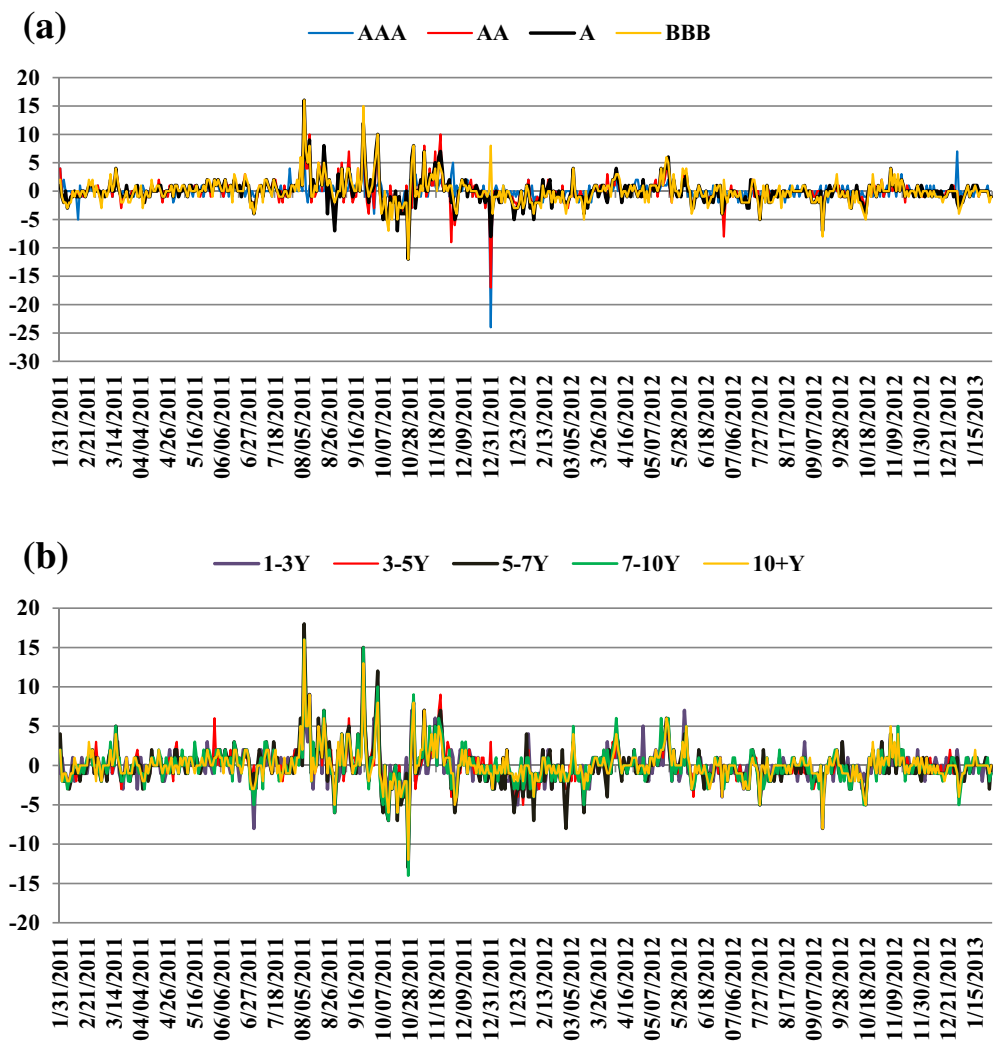

Fig. 2 a Changes in US Dollar corporate credit spreads by rating. b Changes in US Dollar corporate credit spreads by maturity

The basic structure of the model is GARCH $(1,1)$, which is given by:

$$
\begin{aligned}
& \Delta Y_{t}=X+\varepsilon_{t} \\
& \varepsilon_{t}=z_{t} \sqrt{h_{t}}
\end{aligned}
$$

where $z_{t}$ is a i.i.d.N(0,1) random variable and

$$
h_{t}=\omega+\alpha \varepsilon_{t-1}^{2}+\beta h_{t-1}
$$

In order to account for the size and sign effects within a GARCH structure, we consider two asymmetric models: the GJR-GARCH by Glosten et al. (1993) and the asymmetric GARCH of Engle and $\mathrm{Ng}$ (1993). The models are studied in their most simple structure, when the lag lengths are equal to one. These parsimonious models have proven themselves to perform well.

The asymmetric GARCH $(1,1)$ is given by:

$$
h_{t}=\omega+\alpha\left(\varepsilon_{t-1}-\gamma\right)^{2}+\beta h_{t-1}
$$

The usual restrictions on AGARCH parameters are that $\omega, \alpha$ and $\beta>0$. The GARCH model is, in fact, a restricted version of the AGARCH with $\gamma=0$.

The GJR-GARCH $(1,1)$ is given by:

$$
h_{t}=\omega+\alpha \varepsilon_{t-1}^{2}+\gamma S_{t-1}^{-} \varepsilon_{t-1}^{2}+\beta h_{t-1}
$$


where $\omega, \alpha, \beta$ and $\gamma$ are constant parameters, and $S_{t-1}^{-}$is an indicator function that takes the value 1 when $\varepsilon_{t-1}<0$ and zero otherwise.

As noted above, tests of normality show that the conditional variance does not follow the normal distribution. The Gaussian GARCH-type models consider volatility clustering, but are not sufficient to account for the entire leptokurtosis that appears in the credit spreads data. Fatter-tailed distributions may better characterize the error process. Thus, in order to capture this effect we consider the standardized Student- $t$ distributions as well as the Gaussian as functional forms of the conditional density for both the symmetric and asymmetric GARCH models.

The normal distribution was originally used by Engle (1982) in the ARCH model. Bollerslev (1987), on the other hand, proposed a standardized Student- $t$ distribution with $v>2$ degrees of freedom.

$$
\begin{array}{r}
\varepsilon_{t}=\left(\sqrt{h_{t}}\right)^{1 / 2} \Pi_{t} \\
\Pi_{t} \backsim \operatorname{Student}(v)
\end{array}
$$

The Student- $t$ distribution, which is more peaked and has fatter tails than the normal distribution, corresponds better to the properties of empirical credit spreads series. Its distribution is symmetric around mean zero and for $v>4$, the conditional kurtosis equals $3(v-2) /(v-4)$, which exceeds the normal value of 3 .

\section{Empirical results}

To overcome the prevailing concern about traditional GARCH model's inability to accommodate the leverage effect, volatility persistence, fat tails and skewness, we proposed two asymmetric GARCH models. These model structures were tested against the conventional GARCH $(1,1)$ model using both Gaussian and Student- $t$ distribution assumptions. ${ }^{6}$ In all, six models were estimated. Tables $6,7,8,9,10$ and 11 report the estimation results that are summarized in Table 4. First, we note that the empirical evidence favors asymmetric GARCH models. For most measures, the model selection criteria [Akaike information (AIC) and Schwartz (BIC)] and the log-likelihood values reveal that the AGARCH and the GJR models better estimate the credit spreads. The traditional GARCH model provides the poorer estimates whatever the rating or maturity. Importantly, we also find that the Student- $t$ distribution clearly outperforms the normal distribution. Indeed, the models based on the Student- $t$ distribution generally produce superior selection criteria (AIC, BIC and log-likelihood) to the models that assume the Gaussian distribution.

Now, turning to the individual determinants of changes in credit spreads in Tables $6,7,8$, 9, 10 and 11, we find that the explanatory variables included in our model have significant coefficients in almost all estimates. Credit spread changes are mainly explained by the interest rate conditions, the state of the stock market, the foreign exchange market and the state of liquidity in the corporate bond market. The effect of these factors depends on bond characteristics with respect to rating and maturity.

\footnotetext{
6 We have also tested for the asymmetric effect on the mean using a GARCH-M (1) model with both Normal and Student distributions. GARCH-M adds the heteroskedastic term directly into the equation to measure the response of the dependent variable to the volatility. We find in results, not reported here for reasons of space but available on request, that the GARCH-M terms are positive but the likelihood ratio of the GARCH-M versus other GARCH models tested in the example, is not statistically significant and thus we fail to find evidence for a response to volatility of credit spreads.
} 
Table 4 Summary results for best model based on Tables 6, 7, 8, 9, 10 and 11

\begin{tabular}{llllll}
\hline Ratings & AAA & AA & A & BBB & General \\
\hline $\begin{array}{l}\text { Panel A: } \text { Ratings } \\
\text { Model }\end{array}$ & AGARCH & GJR-GARCH & GJR-GARCH & GJR-GARCH & GJR-GARCH \\
Distribution & Student & Student & Student & Student & Student \\
Log-likelihood & -729.3019 & -893.905 & -919.3302 & -923.0806 & -898.85 \\
AIC & 1484.604 & 1813.81 & 1864.66 & 1872.161 & 1823.7 \\
BIC & 1539.904 & 1869.11 & 1919.96 & 1927.461 & 1879 \\
\hline Maturities & $1-3$ years & $3-5$ years & $5-7$ years & $7-10$ years & +10 years \\
\hline Panel B: Maturities & & & & & \\
Model & GJR-GARCH & GJR-GARCH & GJR-GARCH & AGARCH & AGARCH \\
Distribution & Student & Student & Student & Student & Student \\
Log-likelihood & -952.1411 & -964.686 & -997.000 & -952.9209 & -898.2186 \\
AIC & 1930.282 & 1955.372 & 2020 & 1931.842 & 1822.437 \\
BIC & 1985.582 & 2010.672 & 2075.3 & 1987.142 & 1877.737 \\
\hline
\end{tabular}

This table presents the best model for each bond category based on the Akaike criteria (AIC), the Schwartz criteria (BIC) and log-likelihood

The signs of the estimated coefficients are all consistent with our expectations. The effect of the interest rate is negative, according to the structural approach that explains this phenomenon by the fact that an increase in interest rates leads to an increase of the drift of the process of the firm's value, thereby reducing the probability of default and therefore credit spreads. The interest rate volatility, reflecting the uncertainty regarding future rates, has a positive impact on the dynamics of credit spreads. Increasing the government bond market's risk may result in a higher risk premium on the corporate bond market. This finding demonstrates the importance of a premium rate and highlights one of the limitations of structural models that do not consider interest rate risk. The impact of the slope of the yield curve on credit spread changes is also negative. Indeed, a negative slope of the interest rate may reflect a decline in economic growth which in turn affects business growth, which leads to an increase the probability of default and an increase credit spreads.

In all estimates, returns on the S\&P500 have a positive impact on credit spreads changes, in opposition to the literature that argues that the performance of a stock index is an important indicator of the activity of the private sector such that an increase in stock prices should reduce the risk of default and lead to a decline in risk premiums. This discrepancy can be explained in our study by the fact that the study period (January 2011-January 2013) is a fragile period of crisis. Thus, even though we are seeing positive market returns, investors in the bond market have not yet regained their confidence in the financial markets. Given the uncertainty associated with the impact of the financial crisis on the real economy, risk aversion becomes more important, and, in case of default, investors expect lower recovery rates and require higher risk premiums. The S\&P500's volatility also has a positive impact on the credit spreads, suggesting that an increase in volatility in the stock market reflects higher market risk and leads to an increase in the probability of corporate default.

There is a negative relationship between the liquidity factor and credit spread changes. Since bond markets are often less liquid than the stock market, bond investors require higher premiums to cover the liquidity risk. The premium is even more important when liquidity is low. 
Table 5 Summary of out-of-sample results for model performance

\begin{tabular}{llllll}
\hline Ratings & AAA & AA & A & BBB & General \\
\hline $\begin{array}{l}\text { Panel A: Ratings } \\
\text { Model }\end{array}$ & GJR-GARCH & AGARCH & AGARCH & GJR-GARCH & GJR-GARCH \\
Distribution & Student & Student & Student & Student & Student \\
RMSE & 13,999 & 40,769 & 56,200 & 184,930 & 122,378 \\
MAE & 13,993 & 40,767 & 56,199 & 184,930 & 122,377 \\
Theil's $U$ & 19,863 & 57,584 & 88,392 & 220,869 & 116,281 \\
\hline Maturities & $1-3$ years & $3-5$ years & $5-7$ years & $7-10$ years & +10 years \\
\hline Panel B: Maturities & AGARCH & GJR-GARCH & GJR-GARCH & AGARCH & AGARCH \\
Model & Student & Student & Student & Student & Student \\
Distribution & 39,631 & 73,604 & 119,272 & 116,321 & 141,910 \\
RMSE & 39,621 & 73,602 & 119,271 & 116,320 & 141,910 \\
MAE & 39,705 & 114,373 & 114,373 & 122,853 & 199,277 \\
Theil's $U$ & & & & \\
\hline
\end{tabular}

This table summarizes the out of sample results with three error indicators of sample forecasting: the root mean square error (RMSE), the mean absolute error (MAE) and the Theil's $U$ statistics.

The statistics are calculated as:

$R M S E=\sqrt{\frac{1}{N} \sum_{t=T+1}^{T+N}\left(\hat{Y}_{t}^{2}-Y_{t}^{2}\right)^{2}} ; \quad M A E=\frac{1}{N} \sum_{t=T+1}^{T+N}\left|\hat{Y}_{t}^{2}-Y_{t}^{2}\right| ; \quad U=\sqrt{\frac{\sum_{t=1}^{N-1}\left(\frac{\hat{Y}_{t+1}-Y_{t+1}}{Y_{t}}\right)^{2}}{\sum_{t=1}^{N-1}\left(\frac{Y_{t+1}-Y_{t}}{Y_{t}}\right)^{2}}}$

With: $\hat{Y}$ the estimated credit spreads, $Y$ the observed credit spreads, $N$ the number of previsions' days

Finally, the real effective exchange rate has a positive impact on the dynamics of credit spreads. Credit spreads changes are increasing with the appreciation of the US Dollar. The dollar bond indices are composed largely of American companies that issue debt in local currency. Appreciations in the US dollar may therefore significantly affect the competitiveness and the balance of these companies, especially those with international exposure. Moreover, the dollar is considered as an international currency and is often chosen by foreign companies to denominate their foreign debt. Dollar bond indices therefore have many foreign firms whose dollar debts increase in terms their local currency when the US Dollar appreciates.

\section{Out-of-sample robustness tests}

As a robustness check we follow Lee (1991), Heynen and Kat (1994) and Poon and Granger (2003) and perform out-of-sample tests with a 10 day horizon for the six models tested in Tables 6, 7, 8, 9, 10 and 11. These out-of-sample results based on the root mean squared error (RMSE), mean absolute error (MEA) and the Theil Criterion, reported in Table 12 in "Appendix 2" are summarized in Table 5, are interesting. First, we note that one of the two asymmetric GARCH models with the Student- $t$ distribution always gives the best outof-sample results whatever the rating or the maturity. For AAA and BBB rated bonds, the GJR Student- $t$ model gives the best results. For AA and A rated bonds it is the AGARCH Student- $t$ model that gives the best results. When bonds are broken down by maturity, the AGARCH Student- $t$ model is best for maturities of 1-3, 7-10 and more than 10 years, while the GJR Student- $t$ model is best for maturities of 3-5 and 5-7 years. When all bonds are taken together, the GJR Student- $t$ model performs best based on the RMSE and the MEA. Based 
on the Theil Criterion it is the AGARCH Student- $t$ model that performs best. These results corroborate those in Tables 6, 7, 8, 9, 10 and 11 where the traditional GARCH model and the Gaussian distribution provide poorer estimates whatever the rating or maturity.

\section{Summary and conclusion}

Based on the structural approach to assessing risky debt, we propose asymmetric GARCH models with a Student- $t$ distribution to examine the impact of a broad set of financial variables on US Dollar corporate yield spreads. The GARCH effect addresses the time varying volatility, while the asymmetry addresses the skewness and the Student- $t$ distribution deals with the thick tails that are observed in the credit spread data. The results show that the asymmetric GARCH models with Student- $t$ distributions are superior to the conventional GARCH model and Gaussian distribution in both the in-sample and out-of-sample testing.

Our model includes seven explanatory variables: the risk free interest rate, interest rate volatility, the slope of the yield curve, the stock market return, bond market liquidity and the real effective exchange rate. All the explanatory variables included in our model have significant coefficients with the expected signs in almost all estimates. The effect of these factors varies with respect to rating and maturity.

Our results are interesting for a number of reasons. First of all, they show that when the effects of time varying volatility, skewness and fat tails are taken into consideration, the variables highlighted in the structural default models are important determinants of changes in credit spreads. This stands in contrast to the many studies that find only weak empirical support for the structural models. Importantly, these results hold for almost all maturities and ratings. Secondly, our results show that there is evidence of a strong, significant international effect on credit spreads. This effect is reflected in the negative relationship between credit spreads and the exchange rate. Interestingly, it is significant for all maturities and all but AAA ratings in all the models. Having been overlooked in most previous credit spread studies, it warrants more research scrutiny, especially with respect to the transmission mechanisms between the exchange rate and firm performance. Third, we show that overall estimations can be improved by using the asymmetric GARCH model with fat-tailed densities. Compared to the traditional GARCH model, the AGARCH and GJR-GARCH models provide a better description and more parsimonious representation of credit spread data. They also allow for the increased flexibility provided by the Student- $t$ specification. This result holds for all rating categories and maturities and is robust to in-sample and out-of-sample testing with significant implications for risk management and the pricing of credit derivatives. Finally and importantly for practical investment and financing applications, these results hold for out-of-sample testing up to 10 days in the future.

Open Access This article is distributed under the terms of the Creative Commons Attribution 4.0 International License (http://creativecommons.org/licenses/by/4.0/), which permits unrestricted use, distribution, and reproduction in any medium, provided you give appropriate credit to the original author(s) and the source, provide a link to the Creative Commons license, and indicate if changes were made.

\section{Appendix 1}

See Tables 6, 7, 8, 9, 10 and 11.

\section{Appendix 2}

See Table 12. 


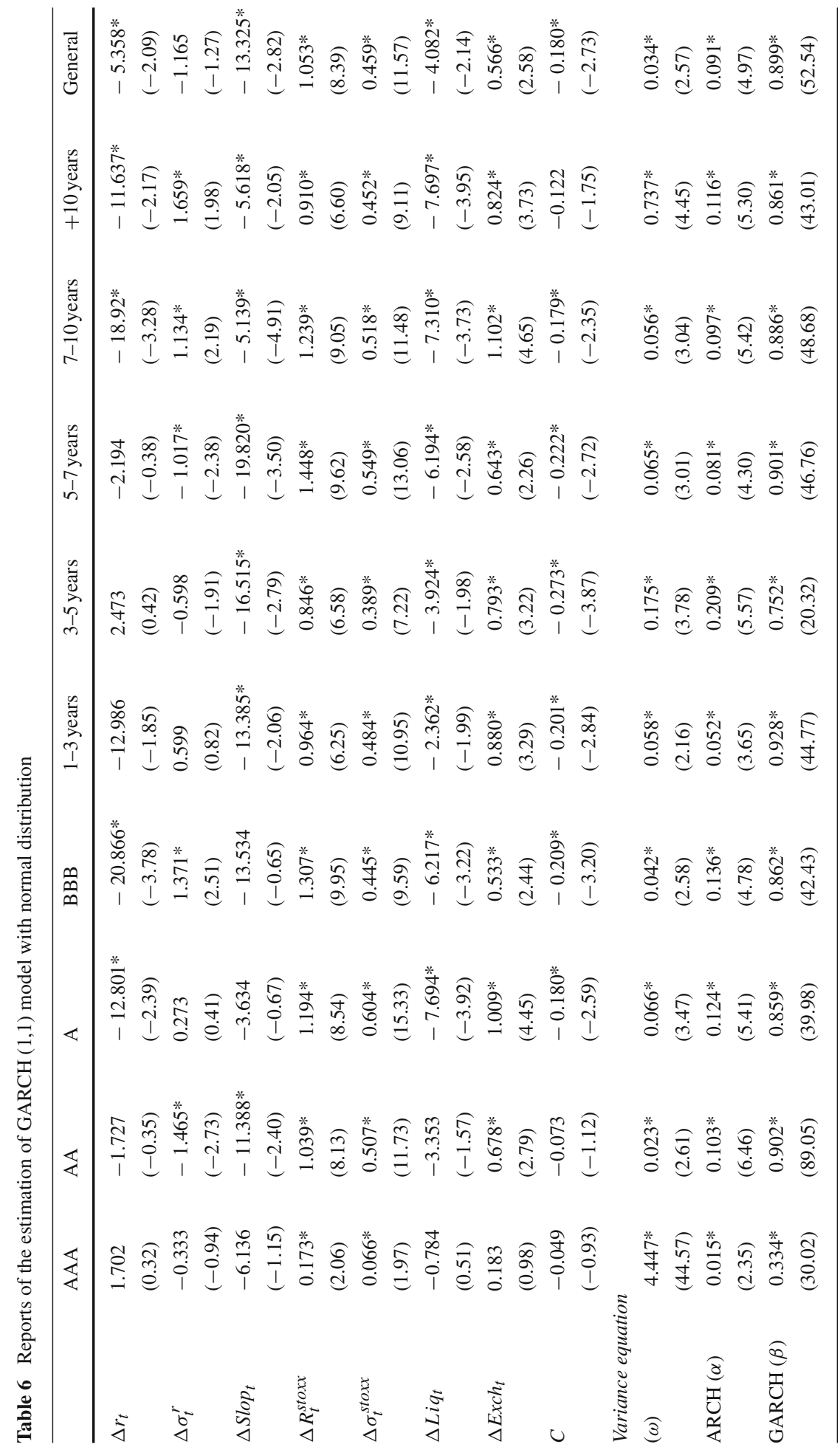




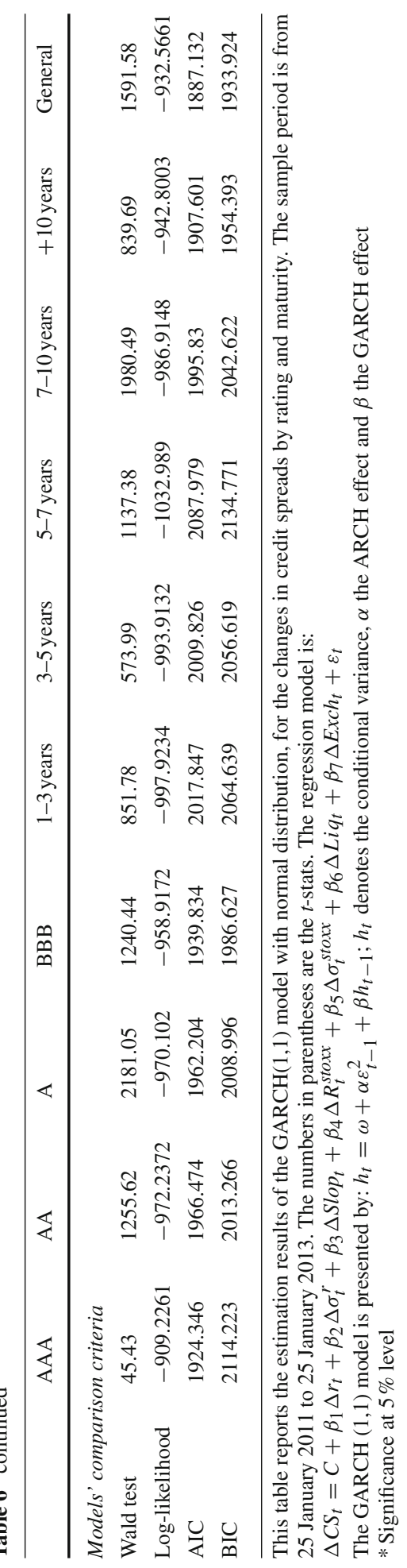

\section{照 Springer}




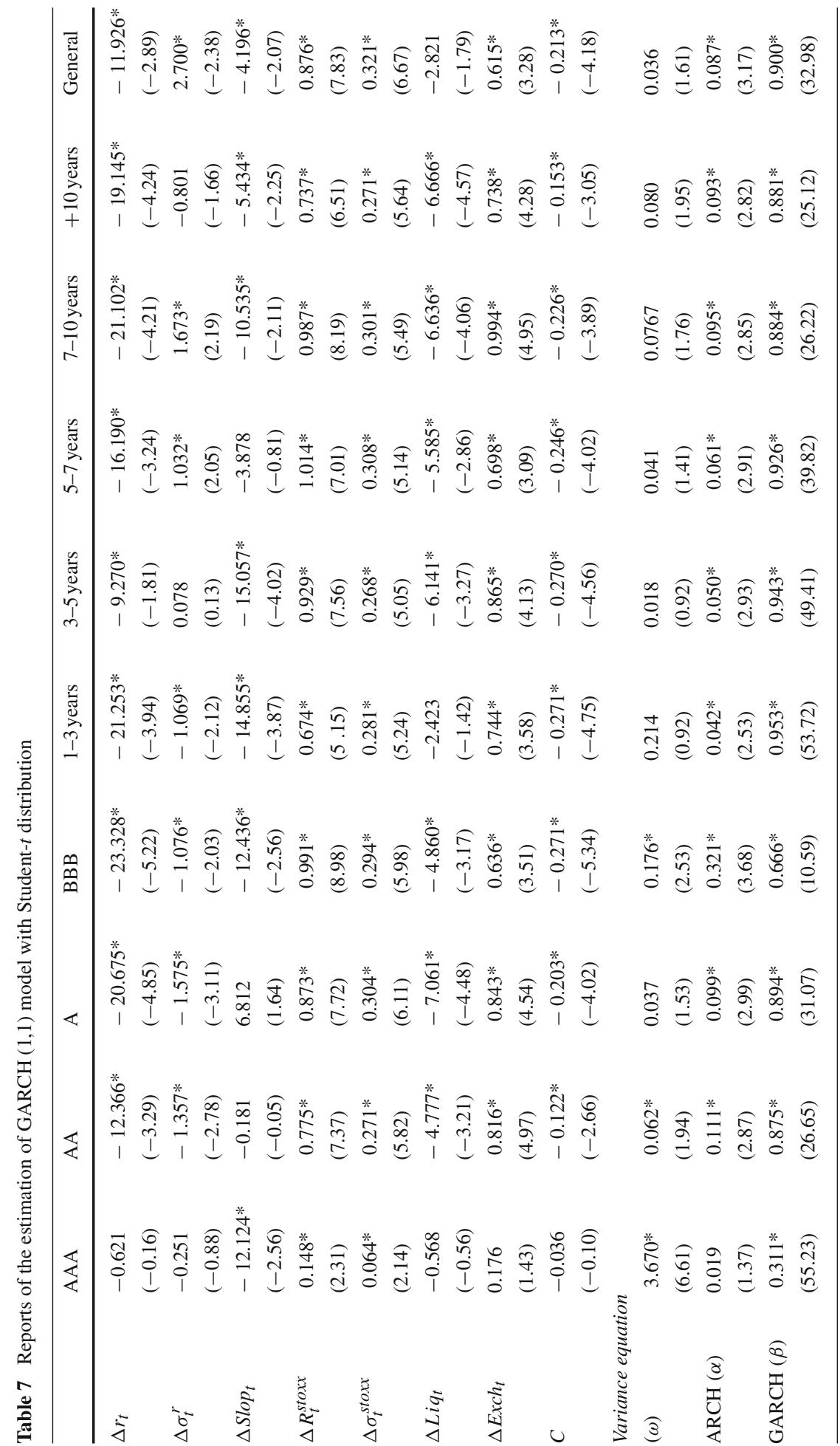




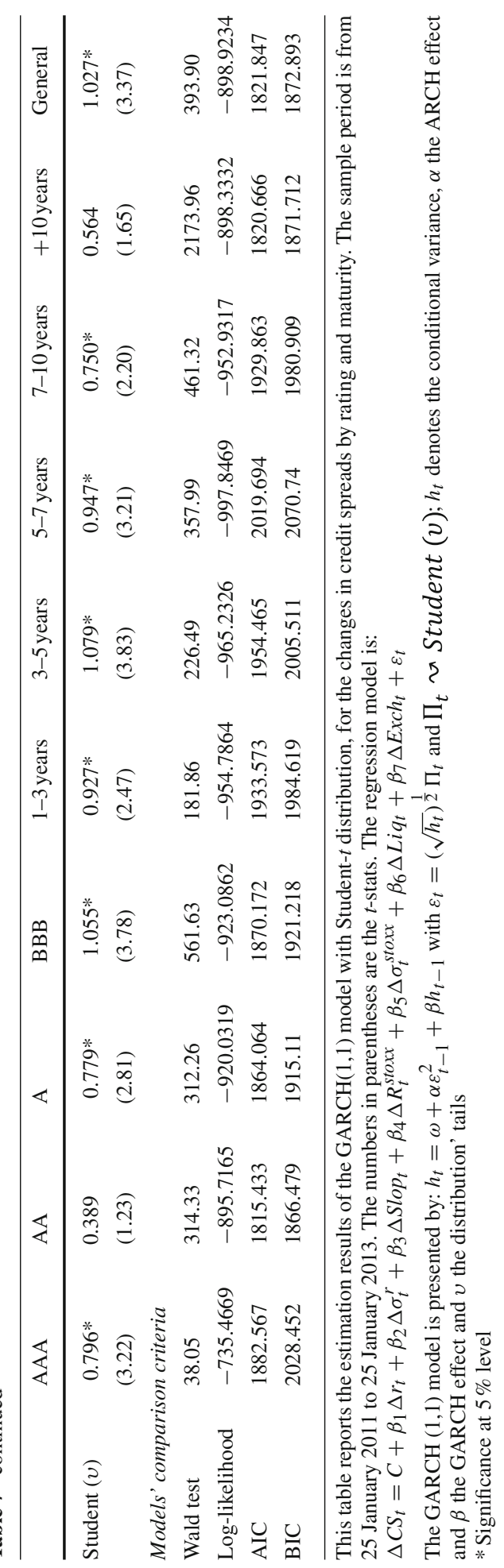




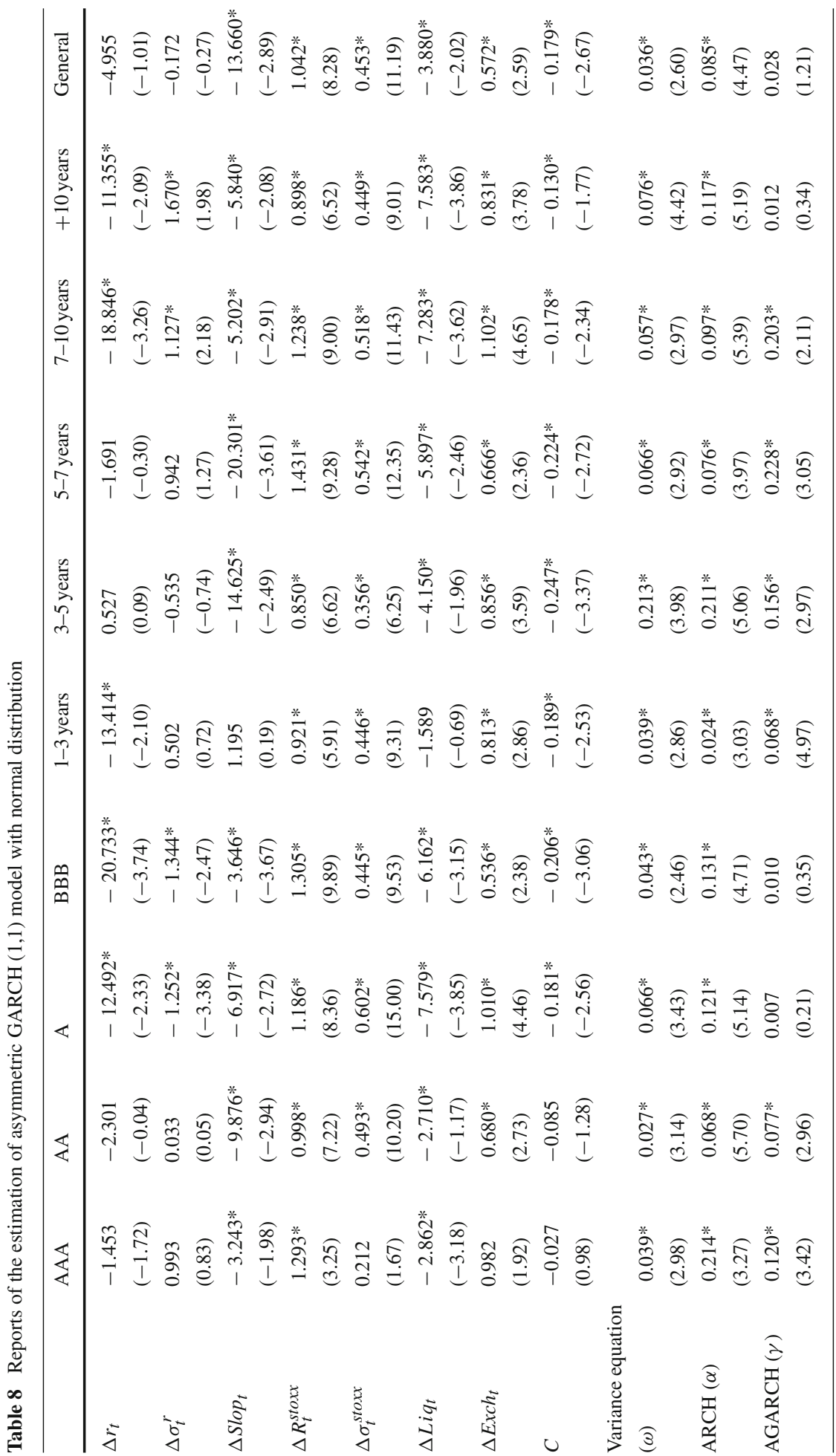




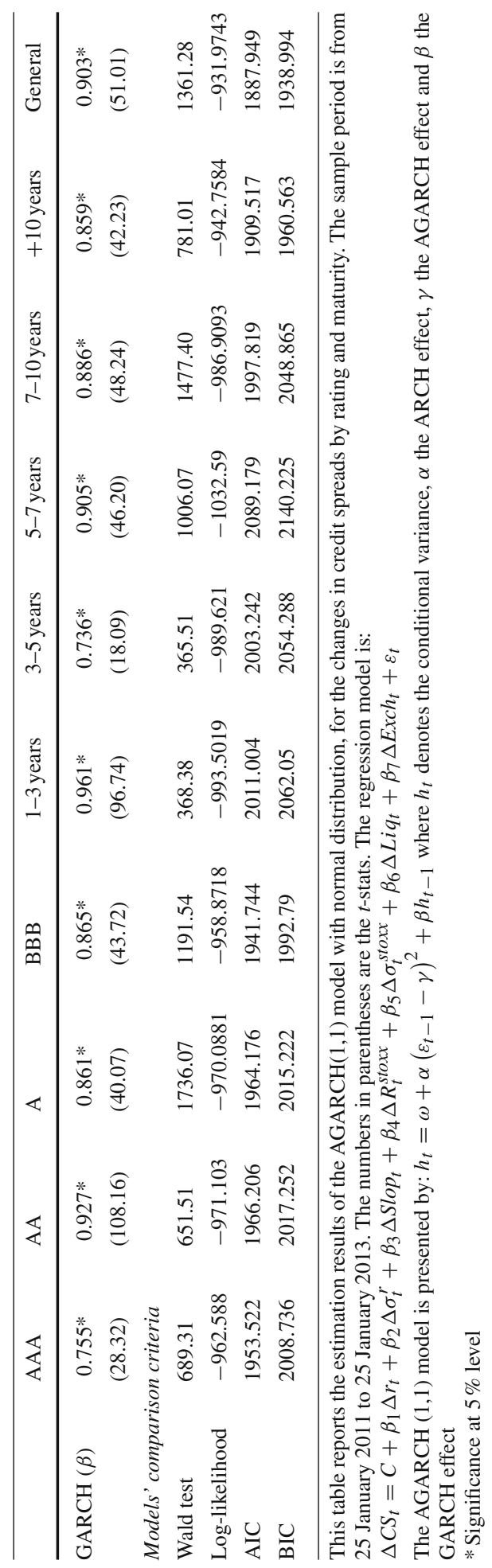




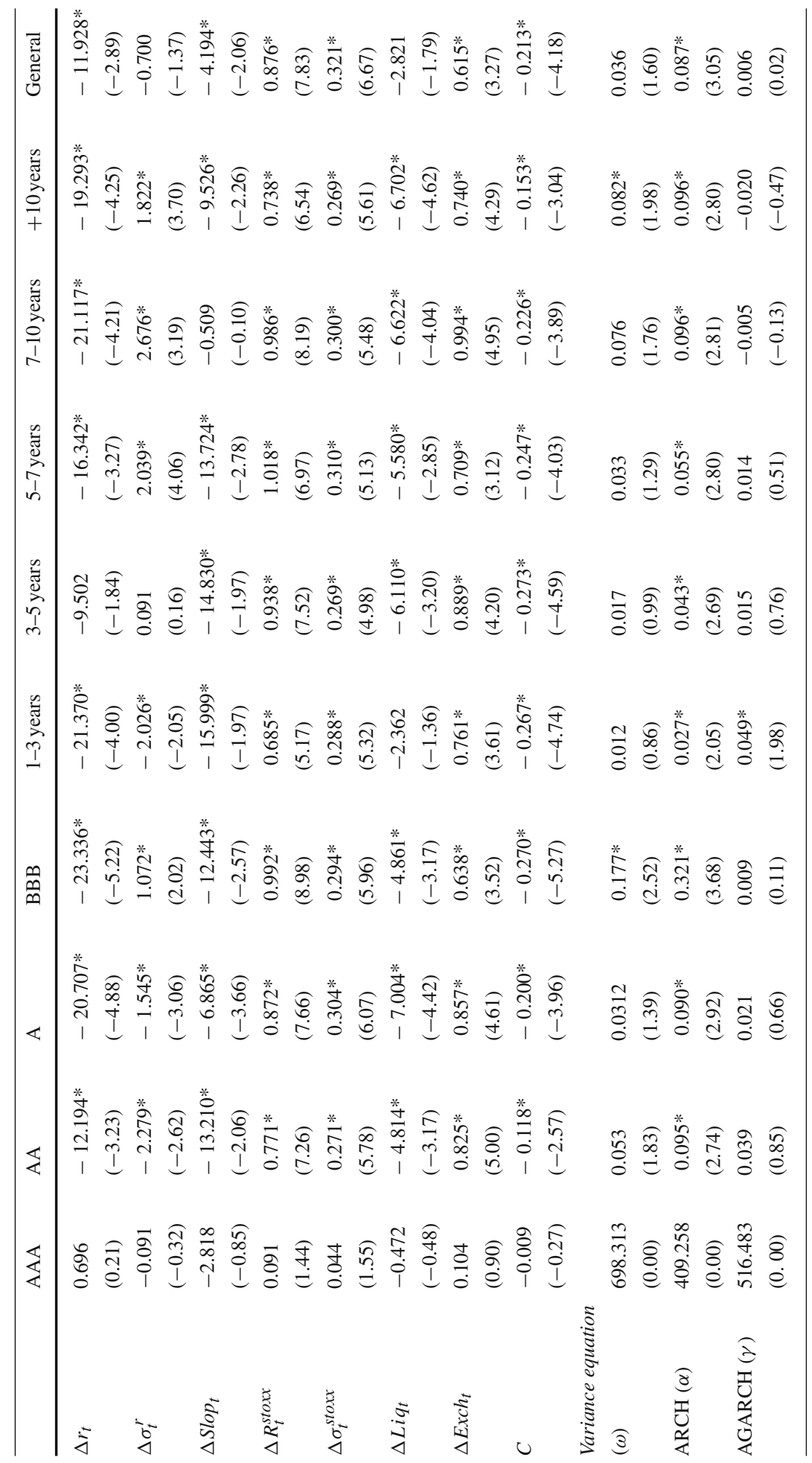




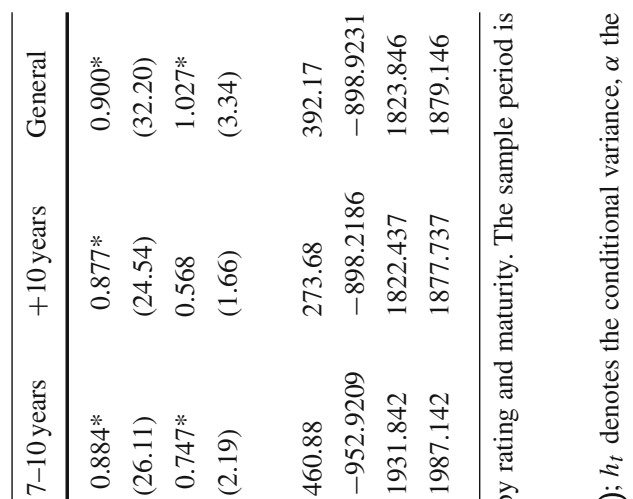

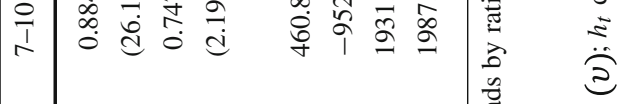

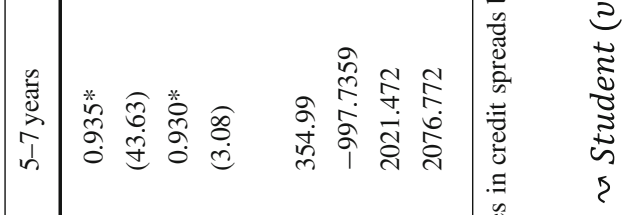

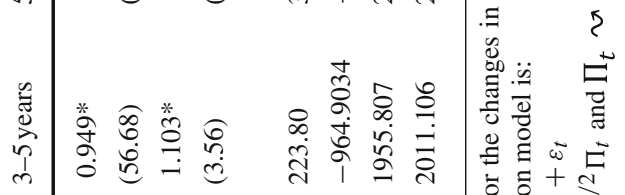

$$
\begin{aligned}
& \text { n) }
\end{aligned}
$$

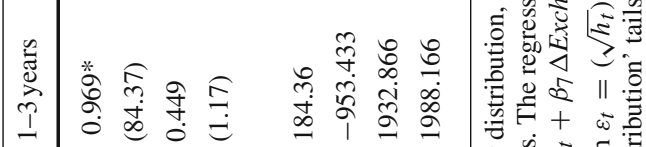

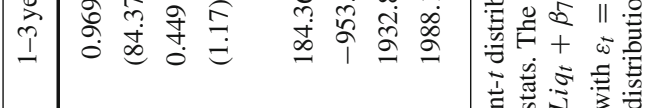

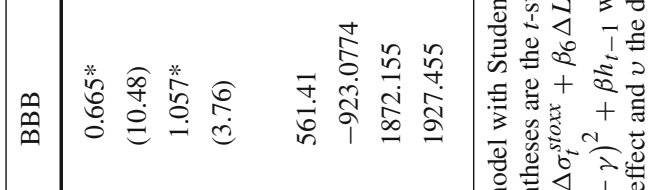

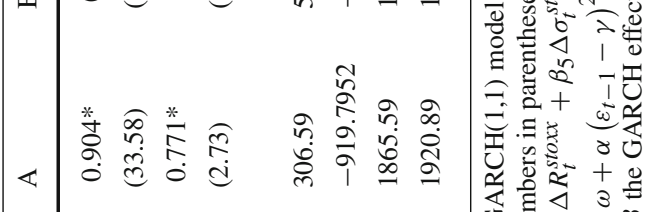

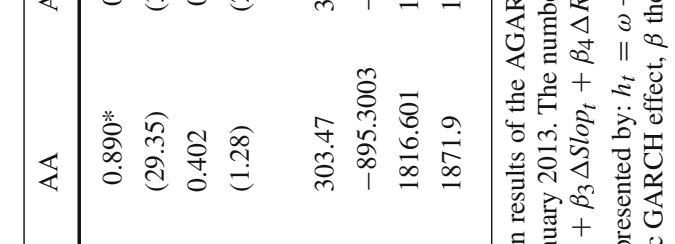

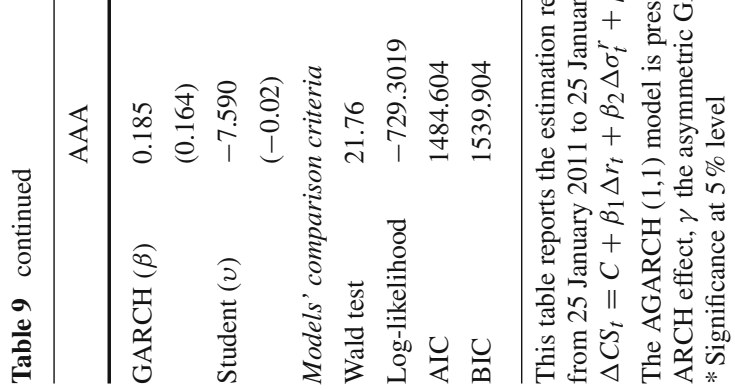




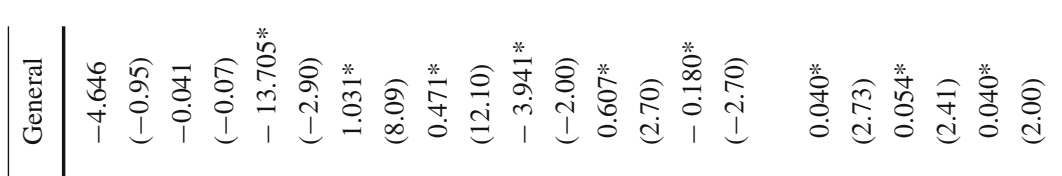

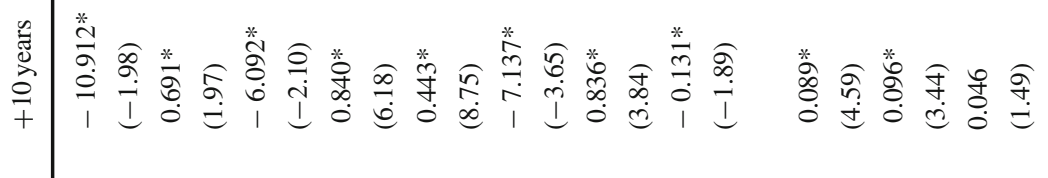

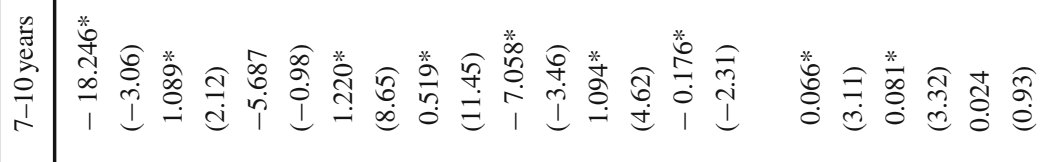

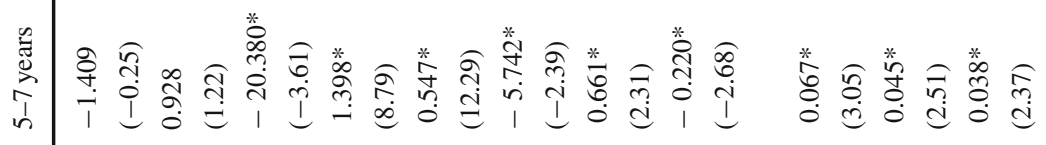

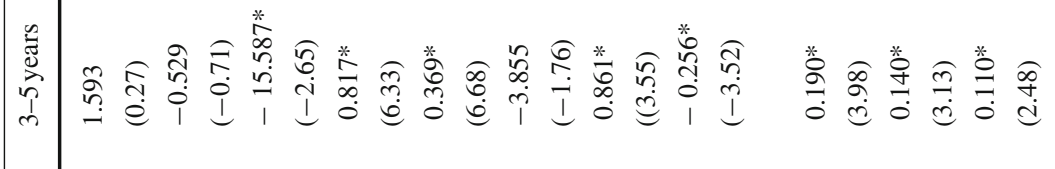

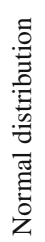

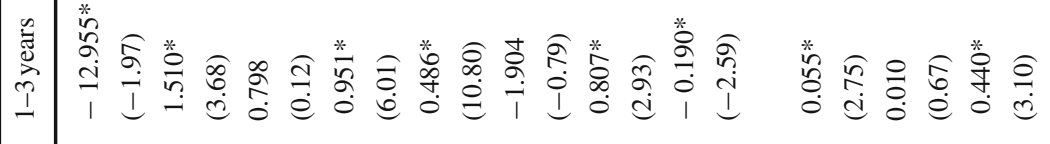

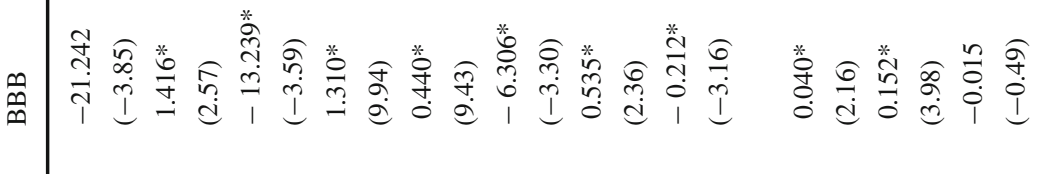

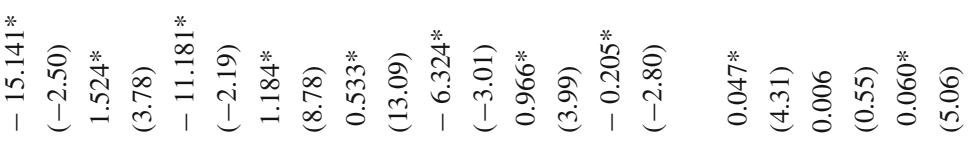

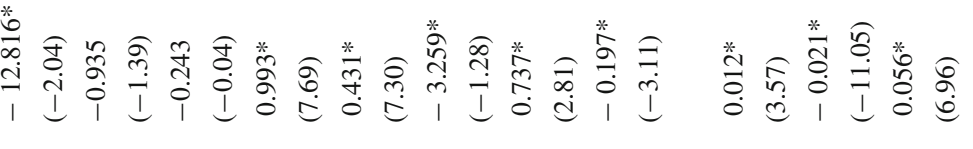

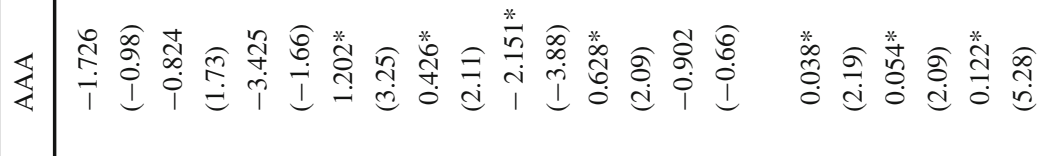

$\cong$

잉

产

s.

产 


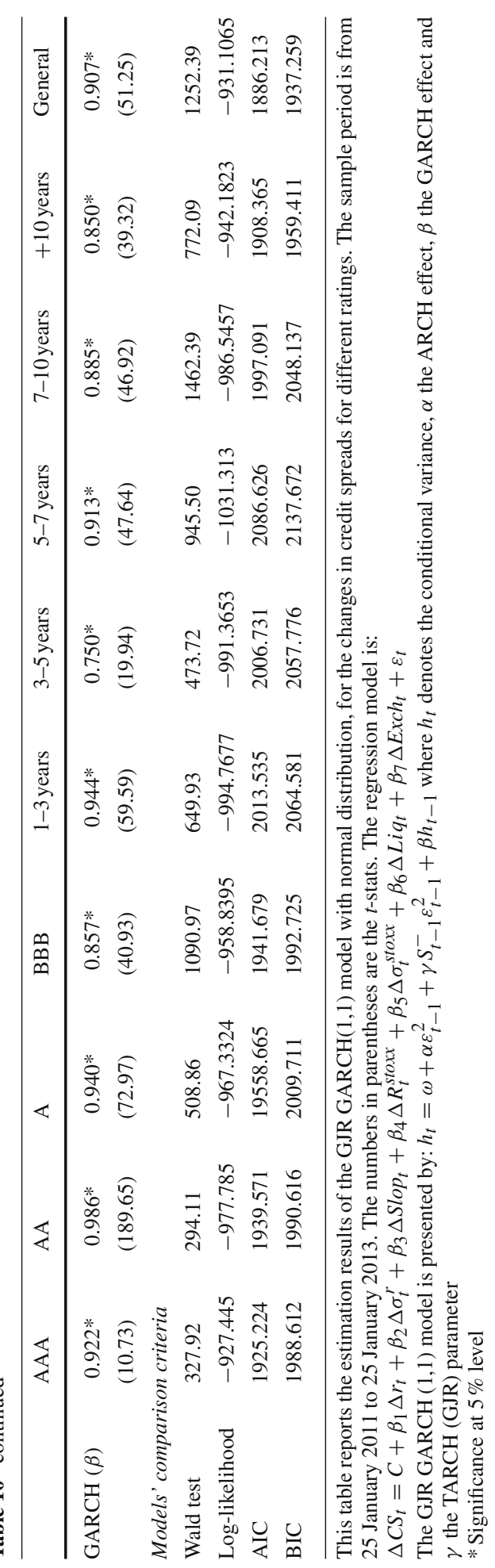




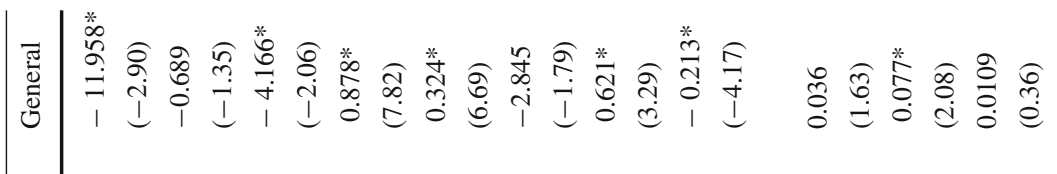

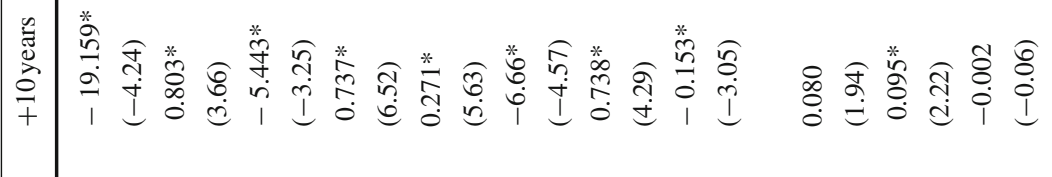

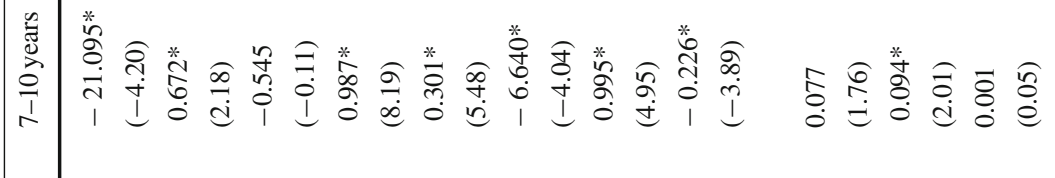

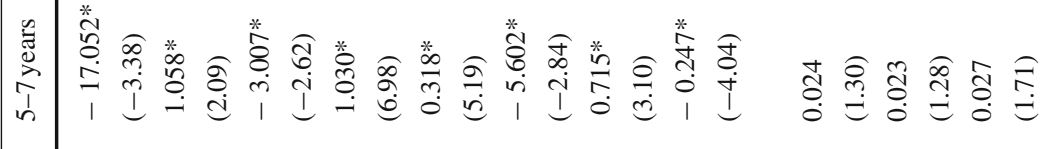

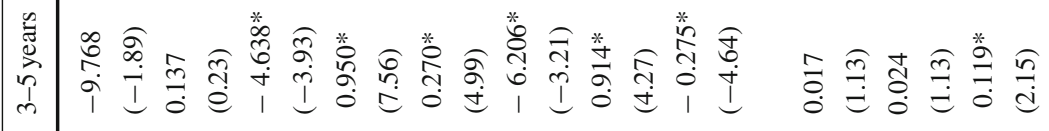

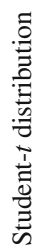

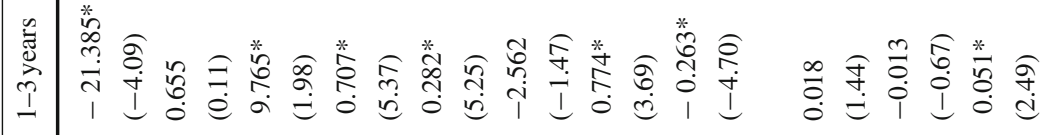

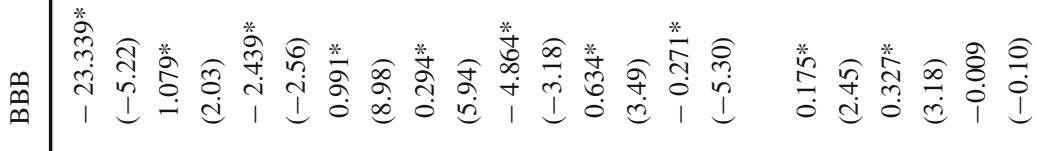

急

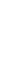

$$
\begin{aligned}
& \begin{array}{l}
8 \\
0 \\
0 \\
0 \\
0 \\
0 \\
0 \\
0 \\
0
\end{array}
\end{aligned}
$$

*

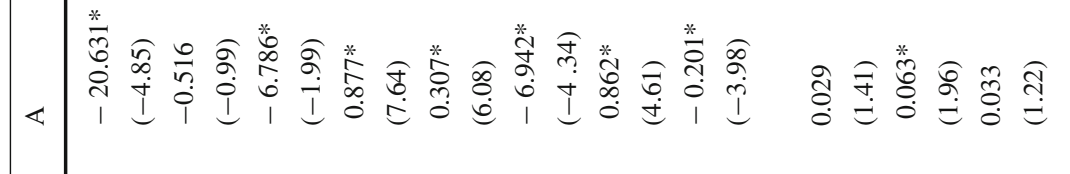

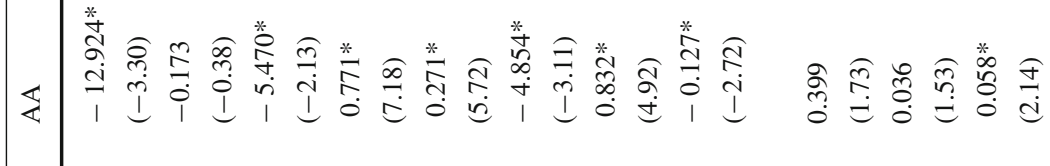

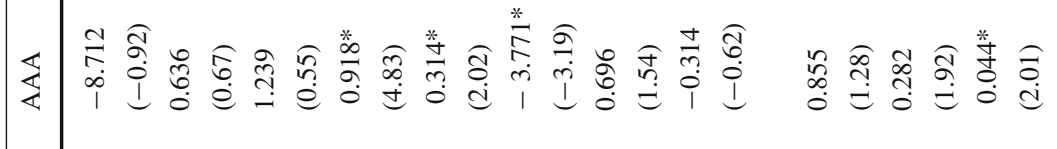

章

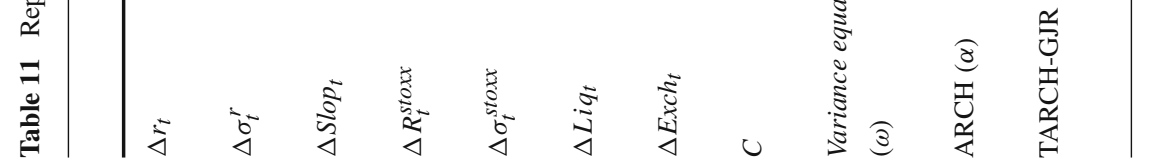




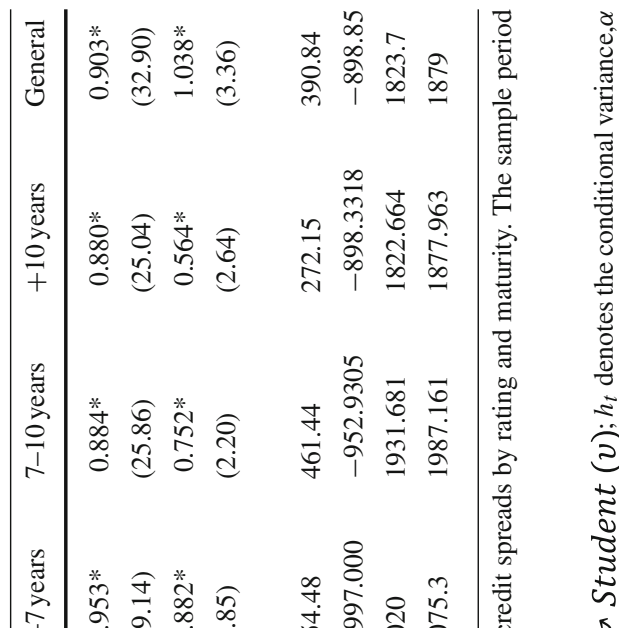

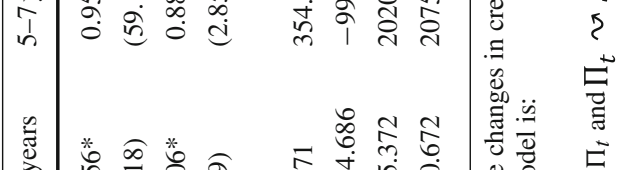

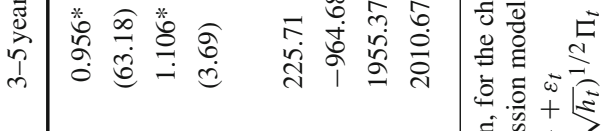

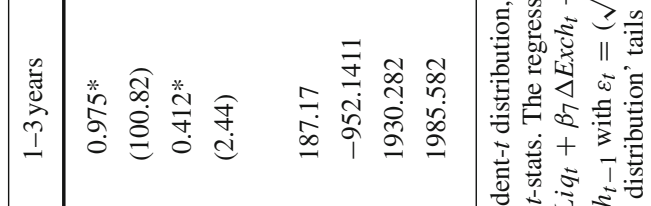

$$
\begin{aligned}
& * a * \quad \infty \quad \infty
\end{aligned}
$$

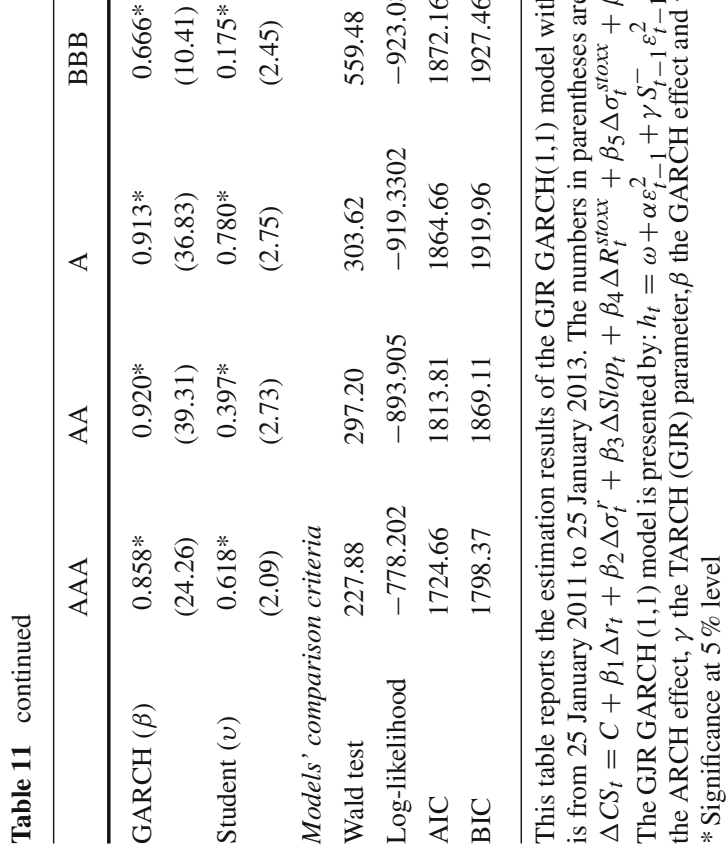




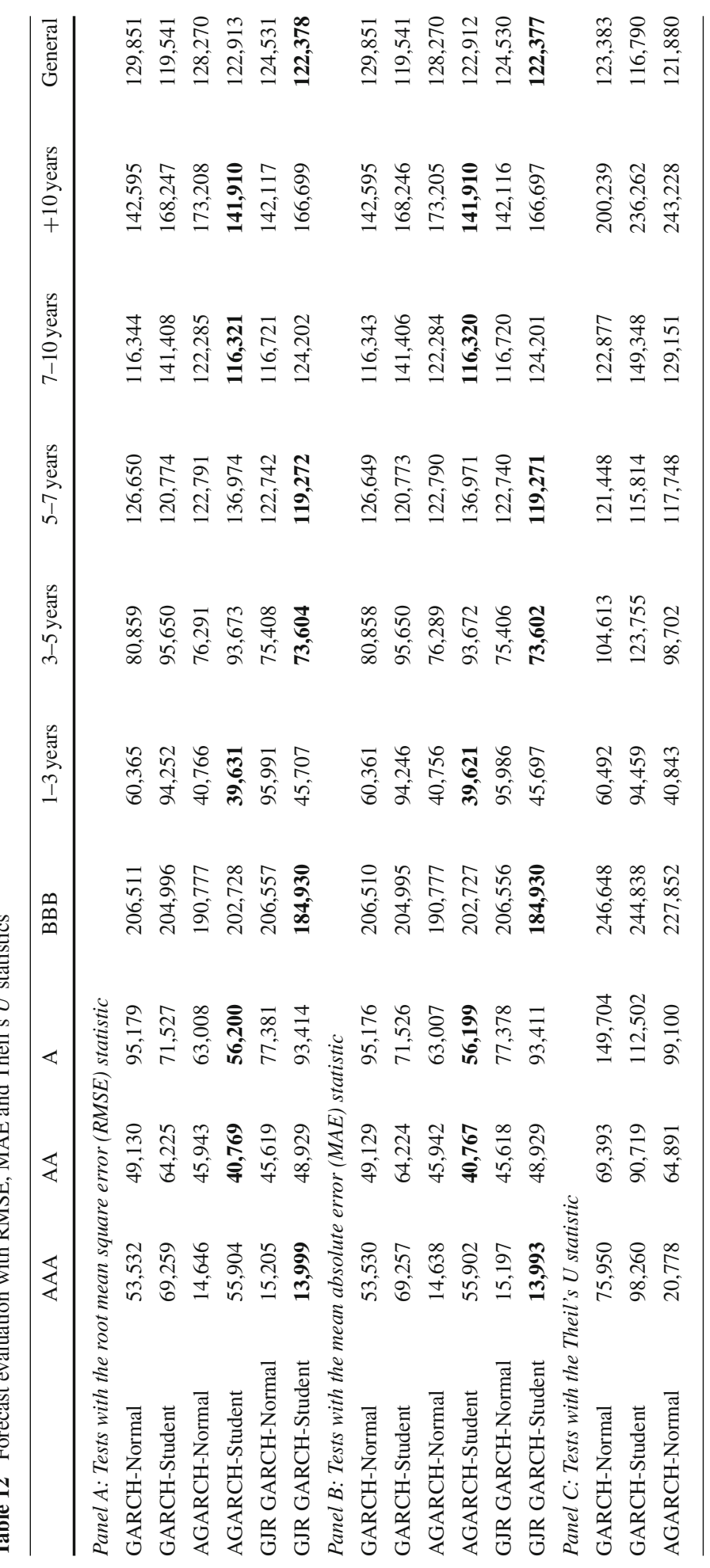




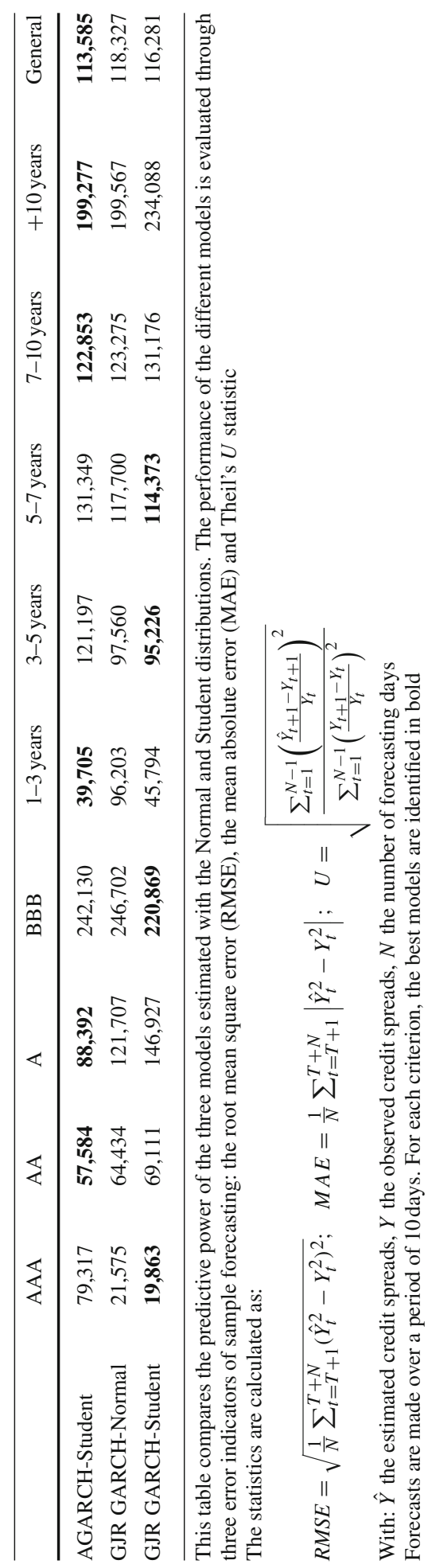




\section{References}

Alizadeh, A. H., \& Gabrielsen, A. (2013). Dynamics of credit spreads moments of European corporate bond indexes. Journal of Banking and Finance, 37(8), 3125-3144.

Agarwal, S., \& Ramaswami, S. N. (1992). Choice of foreign market entry mode: Impact of ownership, location and internationalization factors. Journal of International Business Studies, 23(1), 1-28.

Amihud, Y. (1994). Exchange rates and the valuation of equity shares. In Y. Amihud \& R. Levich (Eds.), Exchange rates and corporate performance (pp. 49-59). New York: Irwin.

Avramov, D., Chordia, T., Jostova, G., \& Philipov, A. (2007). Momentum and credit rating. The Journal of Finance, 62(5), 2503-2520.

Bernard, H., \& Gerlach, S. (1998). Does the term structure predict recessions? The international evidence. International Journal of Finance and Economics, 3(3), 195-215.

Black, F., \& Scholes, M. (1973). The pricing of options and corporate liabilities. Journal of Political Economy, 81(3), 637-654.

Blume, M., Keim, D. B., \& Patel, S. A. (1991). Returns and volatility of low-grade bonds 1977-1989. The Journal of Finance, 46(1), 49-74.

Bodnar, G. M., \& Gentry, W. M. (1993). Exchange rate exposure and industry characteristics: Evidence from Canada, Japan, and the USA. Journal of International Money and Finance, 12, 29-45.

Bollerslev, T. (1986). Generalized autoregressive conditional heteroscedasticity. Journal of Econometrics, 31, 307-327.

Bollerslev, T. (1987). A conditional heteroskedastic time series model for speculative prices and rates of return. Review of Economics and Statistics, 69, 542-547.

Cai, N., \& Jiang, X. (2008). Corporate bond returns and volatility. Financial Review, 43, 1-26.

Campbell, J. Y., \& Ammer, J. (1993). What moves the stock and bond markets? A variance decomposition for long-term asset returns. Journal of Finance, 48(1), 3-37.

Campbell, R., \& Huisman, R. (2003). Measuring credit spread risk. The Journal of Portfolio Management, 29(4), 121-127.

Campbell, J. Y., \& Taksler, G. (2003). Equity volatility and corporate bond yields. Journal of Finance, 58, 2321-2349.

Castagnetti, C., \& Rossi, E. (2013). Euro corporate bonds risk factors. Journal of Applied Econometrics, 28(3), $372-391$.

Chacko, G. (2005). Liquidity risk in the corporate bond markets. Working Paper, Harvard University and State Street Global Markets.

Chen, R., Yang, L., Wang, W., \& Tang, L. (2014). Discovering the impact of systematic and idiosyncratic risk factors on credit spread of corporate bond within the framework of intelligent knowledge management. Annals of Operations Research, 1-13. doi:10.1007/s10479-014-1727-y.

Choi, J. J., \& Prasad, A. (1995). Exchange risk sensitivity and its determinants: A firm and industry analysis of U.S. multinationals. Financial Management, 24(3), 77-88.

Chordia, T., Sarkar, A., \& Subrahmanyam, A. (2003). An empirical analysis of stock and bond market liquidity. Staff Reports 164, Federal Reserve Bank of New York.

Clark, E. A., \& Mefteh, S. (2011). Asymmetric foreign currency exposures and derivatives use: Evidence from France. Journal of International Financial Management and Accounting, 22, 28-47.

Collin-Dufresne, P., Goldstein, R., \& Martin, S. (2001). The determinants of credit spread changes. Journal of Finance, 56, 2177-2207.

Cornell, B., \& Gren, K. (1991). The investment performance of low-grade bond funds. The Journal of Finance, 46(1), 29-48.

Cremers, M., Driessen, J., Maenhout, P., \& Weinbaum, D. (2008). Individual stock-option prices and credit spreads. Journal of Banking and Finance, 32(12), 2706-2715.

De Jong, F., \& Driessen, J. (2012). Liquidity risk premium in corporate bond market. Quarterly Journal of Finance, 2(2), 1250006.

Delianedis, G., \& Geske, R. (2001). The components of corporate credit spreads: Default, recovery, tax, jumps, liquidity and market factors. UCLA, Working Paper.

Donnelly, R., \& Sheehy, E. (1996). The share price reaction of UK exporters to exchange rate movements: An empirical study. Journal of International Business Studies, 27, 157-165.

Downing, C., Underwood, S., Xing, Y. (2007). The relative informational efficiency of stocks and bonds: An intraday analysis. SSRN Working paper.

Driessen, J. (2005). Is default event risk priced in corporate bonds? Review of Financial Studies, 18(1), 165195.

Duffee, G. (1998). The relation between treasury yields and corporate bond yield spreads. Journal of Finance, 53, 2225-2241. 
Duffie, D., \& Singleton, K. J. (1999). Modeling term structures of defaultable bonds. Review of Financial Studies, 12, 687-720.

Elton, E. J., Gruber, M. J., Agrawal, D., \& Mann, C. (2001). Explaining the rate spread on corporate bonds. Journal of Finance, 6(1), 247-277.

Engle, R. F. (1982). Autoregressive conditional heteroskedasticity with estimates of variance of UK inflation. Econometrica, 50, 987-1008.

Engle, R., \& Ng, V. (1993). Measuring and testing the impact of news on volatility. Journal of Finance, 48, 1749-1777.

Ericsson, J., \& Renault, O. (2006). Liquidity and credit risk. Journal of Finance, 61, 2219-2250.

Estrella, A., \& Hardouvelis, G. A. (1991). The term structure as a predictor of real economic activity. Journal of Finance, 46, 555-576.

Estrella, A., \& Mishkin, F. S. (1998). Predicting U.S. recessions: Financial variables as leading indicators. Review of Economics and Statistics, 80, 45-61.

Fama, E. F., \& French, K. R. (1989). Business conditions and expected returns on stocks and bonds. Journal of Financial Economics, 25, 23-49.

Galai, D., \& Wiener, Z. (2012). Credit risk spreads in local and foreign currencies. Journal of Money, Credit and Banking, 44(5), 883-901.

Glosten, R., Jagannathan, R., \& Runkle, D. (1993). On the relation between expected value and the volatility of the nominal excess return on stocks. Journal of Finance, 48, 1779-1801.

Gilchrist, S., \& Zakrajsek, E. (2011). Credit spreads and business cycle fluctuations. nber.org.

Hagelin, N., \& Prambourg, B. (2004). Hedging foreign exchange exposure: Risk reduction from transaction and translation exposure. Journal of International Financial Management and Accounting, 15, 1-20.

He, J., \& Ng, L. K. (1998). The foreign exchange exposure of Japanese multinational corporations. Journal of Finance, 53(2), 733-53.

Heynen, R. C., \& Kat, H. M. (1994). Volatility prediction: A comparison of stochastic volatility, GARCH $(1,1)$ and EGARCH $(1,1)$ models. Journal of Derivatives, 2, 50-65.

Hibbert, M., Pavlova, I., Barber, J., \& Dandapani, K. (2011). Credit spread changes and equity volatility: Evidence from daily data. Financial Review, 46(3), 357-383.

Houweling, P., Mentink, A., \& Vorst, T. (2005). Comparing possible proxies of corporate bond liquidity. Journal of Banking and Finance, 29, 1331-1358.

Huang, J. Z., \& Huang, M. (2012). How much of the corporate-treasury yield spread is due to credit risk? A new calibration approach. The Review of Asset Pricing Studies, 2(2), 153-202.

Jankowitsch, R., \& Pichler, S. (2005). Currency dependence of corporate credit spreads. Journal of Risk, 8(1), $1-24$.

Jarrow, R., \& Turnbull, S. (1995). Pricing derivatives on financial securities subject to default risk. Journal of Finance, 50, 53-86.

Jones, E., Scott, P. M., \& Rosenfeld, E. (1984). Contingent claims analysis of corporate capital structures: An empirical investigation. Journal of Finance, 39, 611-625.

Jorion, P. (1990). The exchange rate exposure of U.S. multinationals. Journal of Business, 63, 331-345.

Kao, D. L. (2000). Estimating and pricing credit risk: An overview. Financial Analysts Journal, 56(4), 50-66.

Keim, D. B., \& Stambaugh, R. F. (1986). Predicting returns in the stock and bond markets. Journal of Financial Economics, 17(2), 357-390.

Kwan, S. H. (1996). Firm-specific information and the correlation between individual stocks and bonds. Journal of Financial Economics, 40, 63-80.

Lee, K. Y. (1991). Are the GARCH models best in out-of-sample performance? Economics Letters, 37, 305308.

Longstaff, F. A., \& Schwartz, E. (1995). A simple approach to valuing risky fixed and floating rate debt. Journal of Finance, 50(3), 789-821.

Lyden, S., \& Saraniti, D. (2000). An empirical examination of the classical theory of corporate security valuation. Barclays Global Investors.

Merton, R. (1974). On the pricing of corporate debt: The risk structure of interest rates. Journal of Finance, $29,449-470$.

Miller, K. D., \& Reuer, J. J. (1998). Firm strategy and economic exposure to foreign exchange rate movements. Journal of International Business Studies, 29(3), 493-514.

Muller, A., \& Verschoor, W. F. (2006). Foreign exchange risk exposure: Survey and suggestions. Journal of Multinational Financial Management, 16, 385-410.

Ogden, J. P. (1987). Determinants of the ratings and yields on corporate bonds: Tests of the contingent claims model. Journal of Financial Research, 10(4), 329-340.

Ohyama, S., \& Sugimoto, T. (2007). The determinants of credit spread changes in Japan. Bank of Japan, Working Paper, $\mathrm{N}^{\circ} 07-\mathrm{E}-4$. 
Pedrosa, M., \& Roll, R. (1998). Systematic risk in corporate bond credit spreads. Journal of Fixed Income, 8, $7-26$.

Perraudin, W. R., \& Taylor, A. P. (2003). Liquidity and bond market spreads. Bank of England, Working Paper $\mathrm{N}^{\circ} 879$

Pesaran, M. H., Schuermann, T., Treutler, B. J., \& Weiner, S. M. (2006). Macroeconomic dynamics and credit risk: A global perspective. Journal of Money Credit and Banking, 38, 1211-1262.

Poon, S. H., \& Granger, C. J. (2003). Forecasting volatility in financial markets: A review. Journal of Economic Literature, 41(2), 478-539.

Ramaswami, M. (1991). Hedging the equity risk of high-yield bonds. Financial Analyst Journal, 47, 41-50.

Shan, H. (1994). Comovements of law-grade debt and equity returns of highly leveraged firms. Journal of fixed Income, 3, 79-89.

Schwartz, K. (2014). Mind the gap: Disentangling credit and liquidity in risk spreads. SSRN Working Paper. Tseng, Y., Chen, T. K., \& Hsieh, Y. T. (2014). Real earnings management uncertainty and corporate credit risk. European Accounting Review, 24(2).

Van Landschoot, A. (2008). Determinants of yield spread dynamics: Euro versus US dollar corporate bonds. Journal of Banking and Finance, 32, 2597-2605. 